
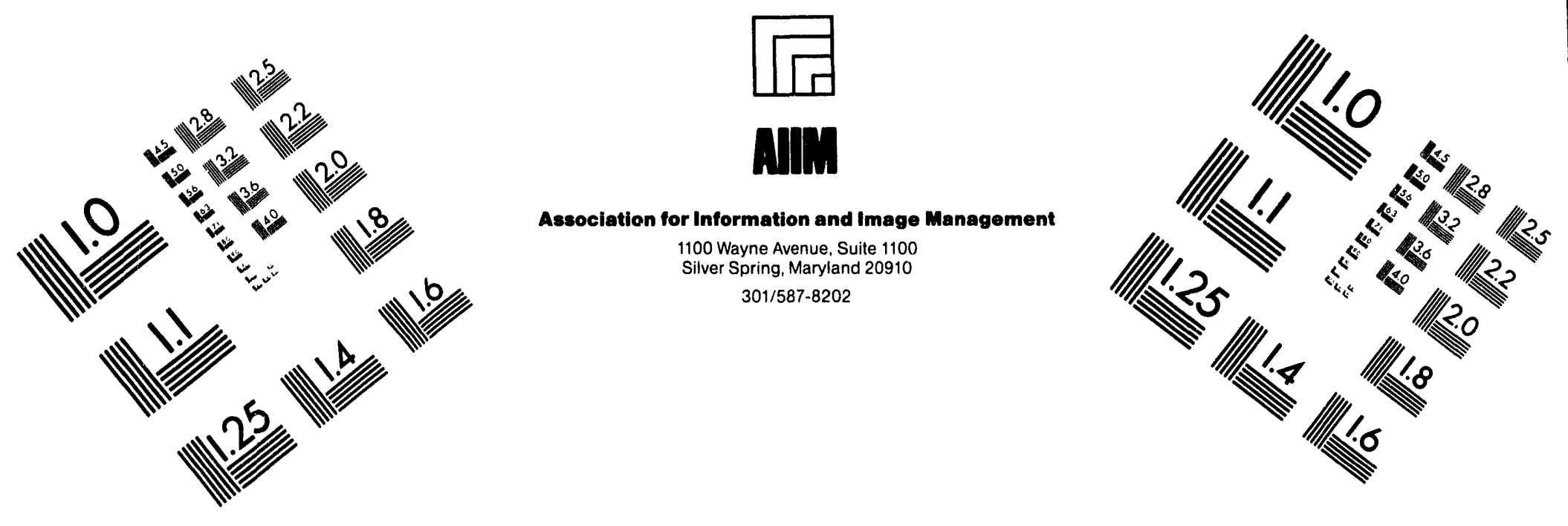

Centimeter

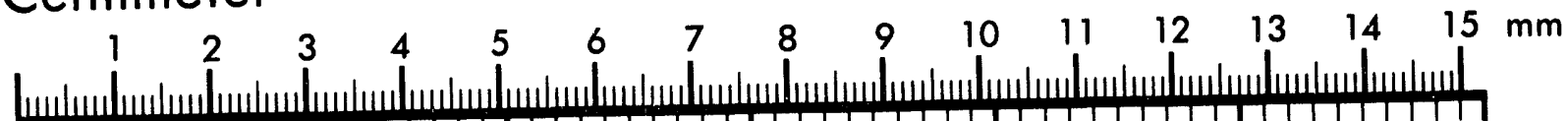

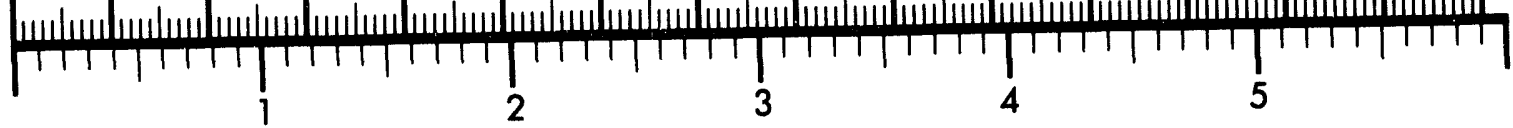
Inches
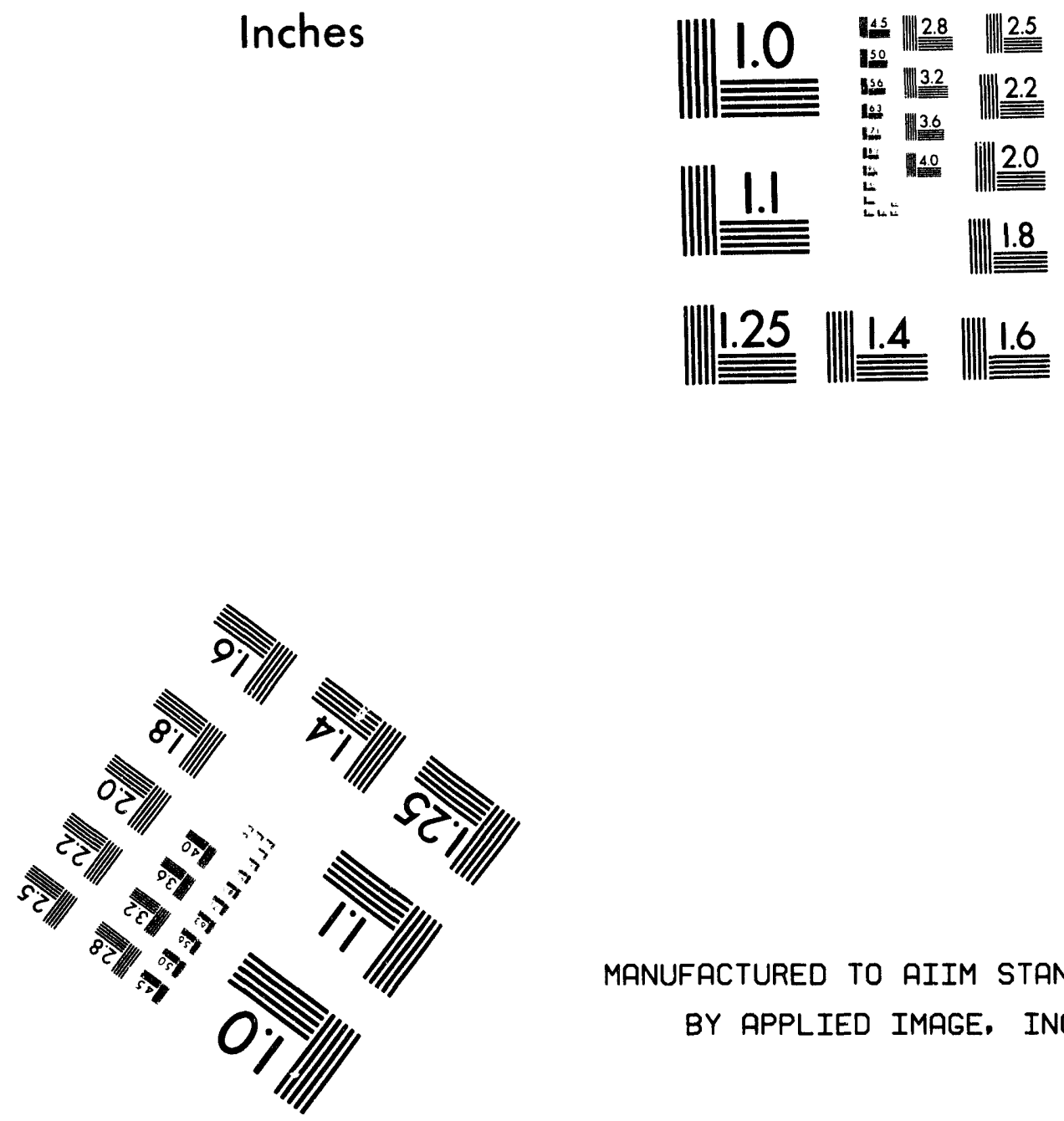

MANUFACTURED TO AIIM STANDARDS BY APPLIED IMAGE. INC.

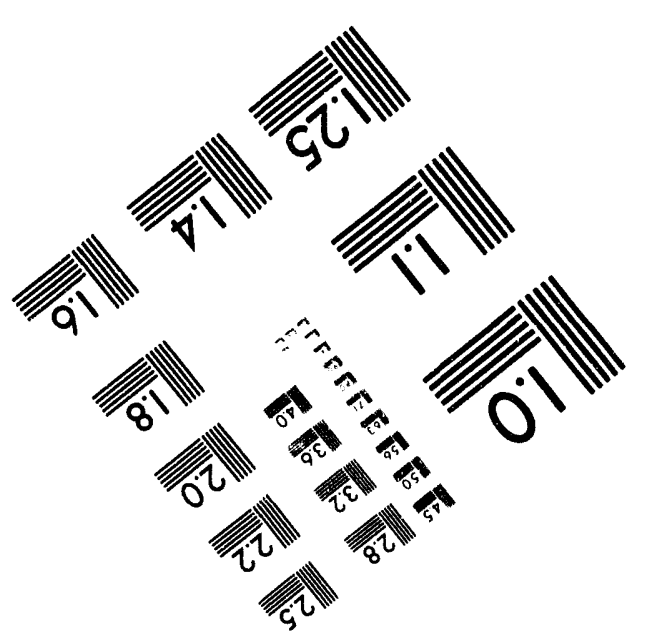



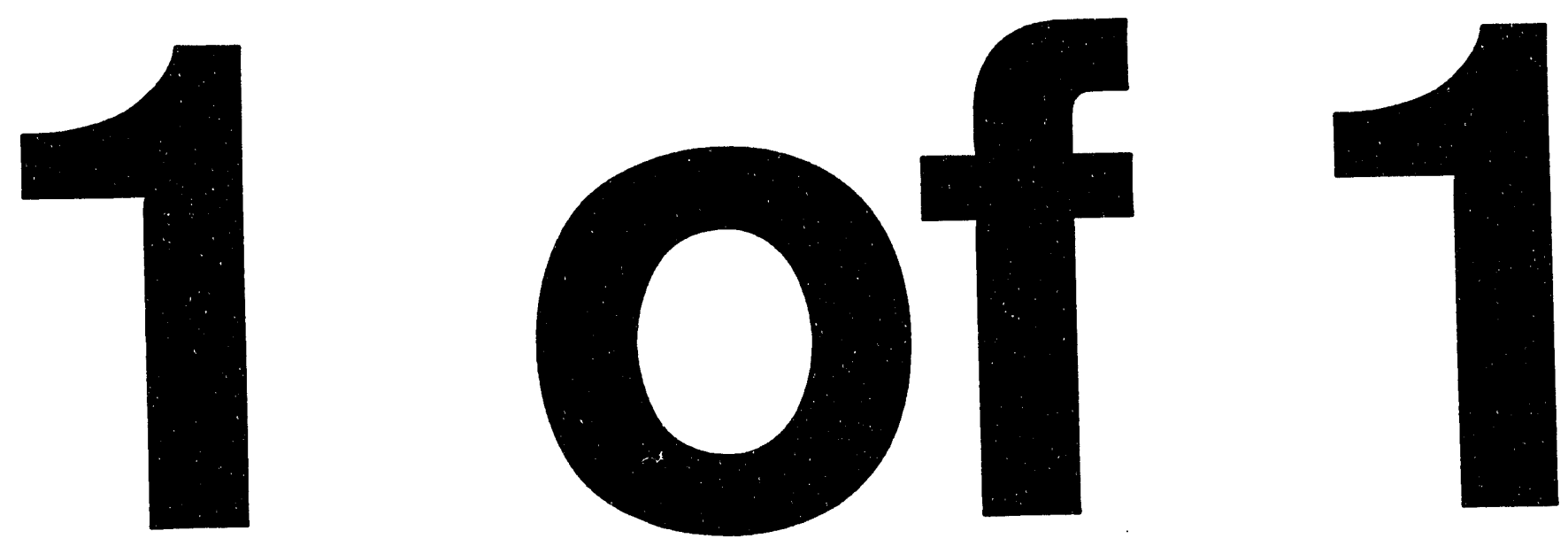


\title{
Buried Waste Integrated Demonstration Technology Preparedness and Status Report Guidance
}

\author{
P. B. Blacker \\ R. W. Bonnenberg \\ P. G. Cannon \\ R. A. Hyde \\ L. R. Watson \\ Published April 1994
Idaho National Engineering Laboratory
EG\&G Idaho, Inc.
Idaho Falls, Idaho 83415

Prepared for the

U.S. Department of Energy

Office of Environmental Restoration and Waste Management

Under DOE Idaho Operations Office

Contract DE-AC07-761D01570

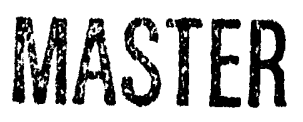

DIETAIEUTION OF THIS DOCUMENT IS UNLIMATED 


\section{Buried Waste Integrated Demonstration Technology \\ Preparedness and Status Report Guidance \\ EGG-WTD-10266, Rev. 1}

Prepared by:

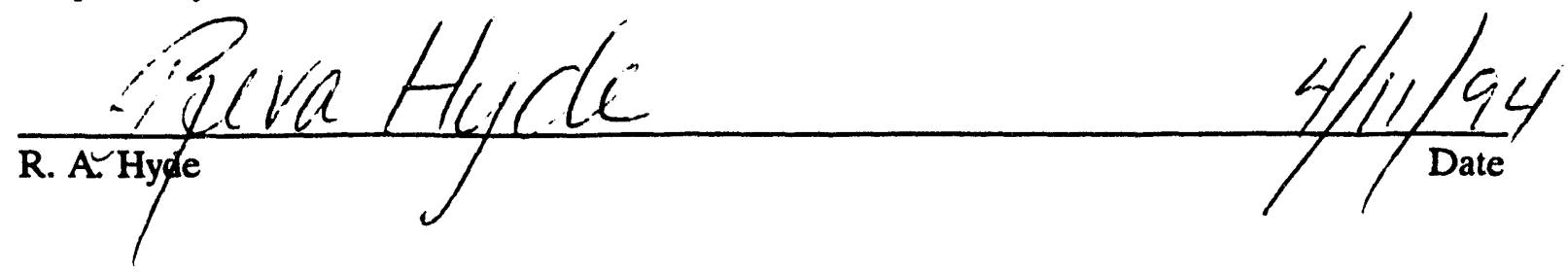

Reviewed by:
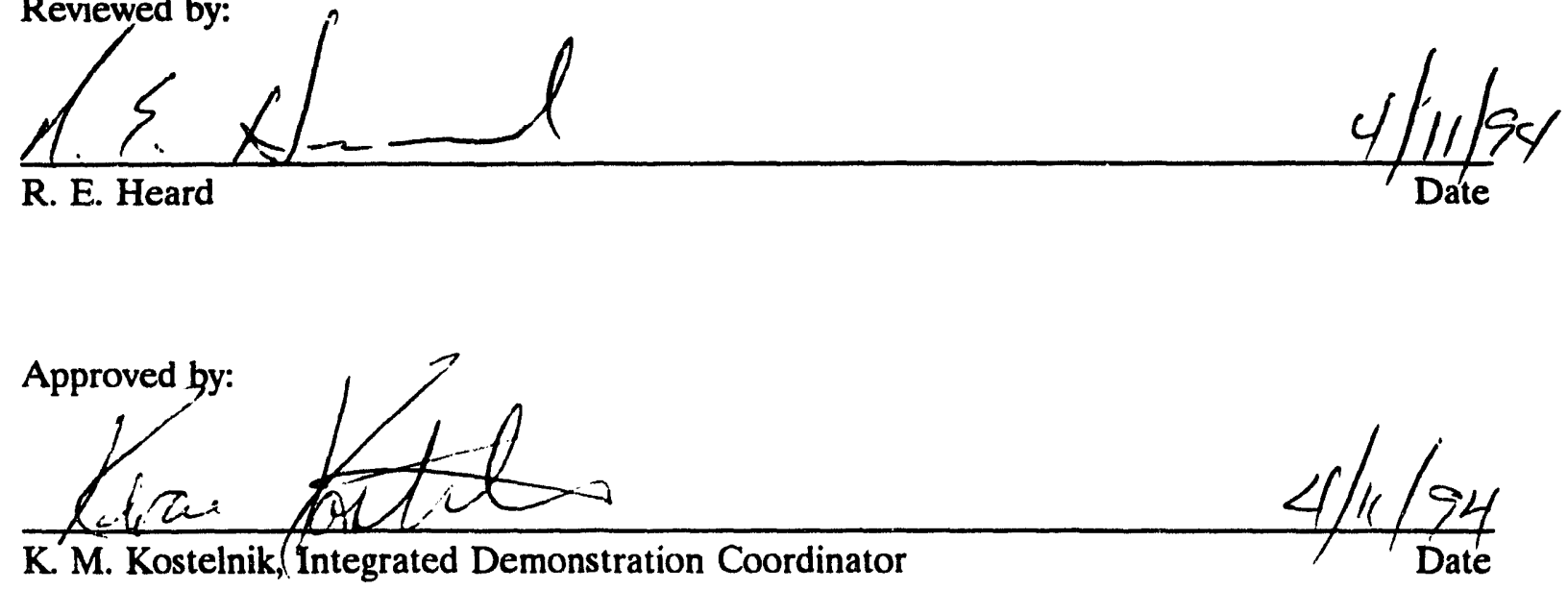


\begin{abstract}
A Technology Preparedness and Status Report is required for each Technical Task Plan funded by the Buried Waste Integrated Demonstration. This document provides guidance for the preparation of that report. Major sections of the report will include a subset of the need for the technology, objectives of the demonstration, technology description and readiness evaluation, demonstration requirements, and preparedness checklist and action plan.
\end{abstract}




\section{SUMMARY}

The Technology Preparedness and Status Report is prepared by the principal investigator and submitted to the Buried Waste Integrated Demonstration one month after funding is approved. The information in Section 2 and 3 of the report will be used by BWID management to assess the readiness of a technology for demonstration and the information in Section 4 will be used by the principal investigator and BWID to begin planning for the demonstration. 


\section{ACKNOWLEDGMENTS}

The authors wish to acknowledge Paul Blacker, Pat Cannon, and Larry Watson who issued the first revision of this document. 


\section{CONTENTS}

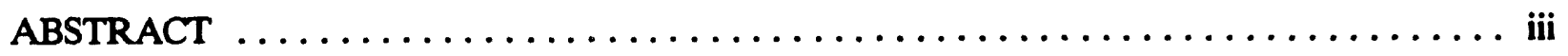

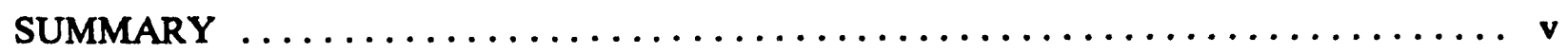

ACKNOWLEDGMENTS $\ldots \ldots \ldots \ldots \ldots \ldots \ldots \ldots \ldots \ldots \ldots \ldots \ldots \ldots \ldots \ldots \ldots$ vii

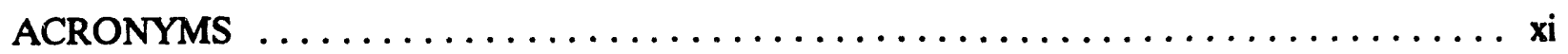

1. INTRODUCTION $\ldots \ldots \ldots \ldots \ldots \ldots \ldots \ldots \ldots \ldots \ldots \ldots \ldots \ldots \ldots \ldots \ldots \ldots \ldots$

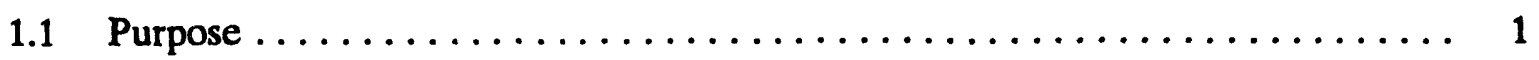

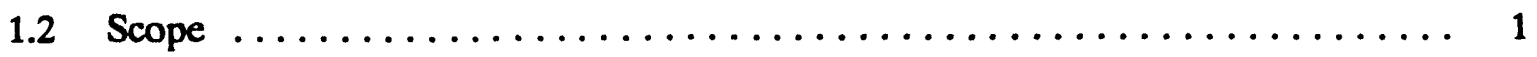

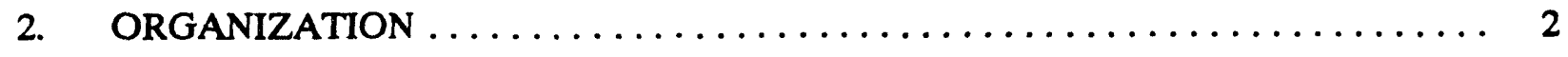

2.1 BWID Program Level Organization $\ldots \ldots \ldots \ldots \ldots \ldots \ldots \ldots \ldots \ldots \ldots, 2$

2.2 Internal INEL Organization and Responsibilities $\ldots \ldots \ldots \ldots \ldots \ldots \ldots, 2$

2.2.1 Technical Program Officer $\ldots \ldots \ldots \ldots \ldots \ldots \ldots \ldots \ldots \ldots \ldots, 2$

2.2.2 Technical Program Manager ...................... 2

2.2.3 Integrated Demonstration Coordinator ................... 2

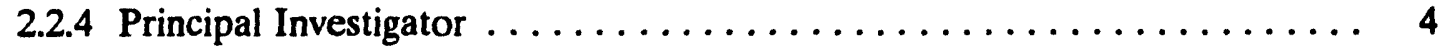

2.2.5 Project/Cost Account Manager ........................ 4

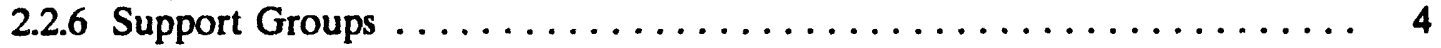

2.2.7 BWID Technical Liaison $\ldots \ldots \ldots \ldots \ldots \ldots \ldots \ldots \ldots \ldots \ldots, 4$

2.2.8 BWID System Integration Program Manager $\ldots \ldots \ldots \ldots \ldots \ldots \ldots, 5$

2.2.9 BWID Deployment Program Manager $\ldots \ldots \ldots \ldots \ldots \ldots \ldots \ldots \ldots$

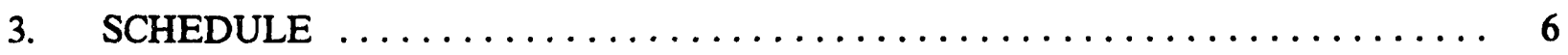

4. TECHNOLOGY PREPAREDNESS AND STATUS REPORT PREPARATION GUIDANCE $\ldots \ldots \ldots \ldots \ldots \ldots \ldots \ldots \ldots \ldots \ldots \ldots \ldots \ldots \ldots \ldots \ldots, 8$

4.1 General Guidance $\ldots \ldots \ldots \ldots \ldots \ldots \ldots \ldots \ldots \ldots \ldots \ldots \ldots \ldots \ldots \ldots$

4.2 Preparedness Checklist and Action Plan $\ldots \ldots \ldots \ldots \ldots \ldots \ldots \ldots \ldots, 8$

Appendix A-Technology Preparedness and Status Report Outline $\ldots \ldots \ldots \ldots \ldots \ldots$ A-1

Appendix B-Preparedness Checklist and Action Plan $\ldots \ldots \ldots \ldots \ldots \ldots \ldots \ldots$ B-3

Appendix C_BWID Technology Commercialization Guide $\ldots \ldots \ldots \ldots \ldots \ldots \ldots$ C-1

Appendix D-Industrial Hygiene Checklist $\ldots \ldots \ldots \ldots \ldots \ldots \ldots \ldots \ldots \ldots \ldots \ldots \ldots \ldots \ldots \ldots \ldots \ldots$

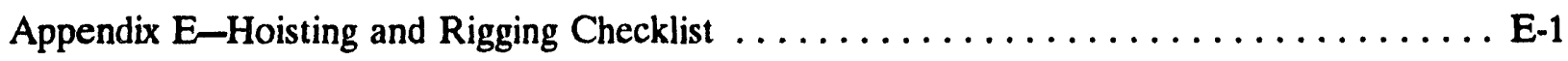




\section{ACRONYMS}

BDPM

BSIPM

BWID

DOE

DOE-HQ

DOE-ID

ER

IDC

INEL

NEPA

OTD

PC\&AP

P/CAM

PI

PPG

TARG

TL

TP\&SR

TPM

TPO

TTP
BWID Deployment Program Manager

BWID Systems Integration Program Manager

Buried Waste Integrated Demonstration

U.S. Department of Energy

U.S. Department of Energy Headquarters

U.S. Department of Energy Idaho Operations Office

Environmental Restoration

Integrated Demonstration Coordinator

Idaho National Engineering Laboratory

National Environmental Policy Act

Office of Technology Development

Preparedness Checklist and Action Plan

Project/Cost Account Manager

principal investigator

Program Planning Group

Technical and Academic Review Group

technical liaison

Technology Preparedness and Status Report

Technical Program Manager

Technical Program Officer

Technical Task Plan 


\section{Buried Waste Integrated Demonstration Technology Preparedness and Status Report Guidance}

\section{INTRODUCTION}

\subsection{Purpose}

The purpose of this document is to provide guidance to the Buried Waste Integrated Demonstration (BWID) principal investigators (PIs) for the development of a Technology Preparedness and Status Report.

This report represents a combination of the Technology Status Report, the BWID questionnaire, and the BWID Preparedness Checklist. This report will provide both the BWID staff and PIs with information that should significantly enhance the effectiveness of budgeting and scheduling activities.

\subsection{Scope}

All BWID-funded projects are required to prepare and submit to the BWID Program Office a Technology Preparedness and Status Report immediately after funding has been approved (draft due 30 days after receipt of funding). Completion of this document (issued as a letter with attachments) is required to retain funding and sponsorship through BWID. Due to the nature of development status of the various programs, some PIs are required to provide different information. For example, a research project or a paper study would not need to provide as much information to BWID as a field demonstration project. This document provides requirements for the different types of projects. 


\section{ORGANIZATION}

\subsection{BWID Program Level Organization}

As the functional program for the Department of Energy (DOE) Office of Technology Development (OTD) for buried waste remediation, BWID actively solicits participation from DOE operations offices, other Federal agencies, universities, and private firms that have applicable intellectual or technological contributions.

Mechanisms for interfacing with DOE Headquarters (DOE-HQ), DOE Idaho Operations Office (DOE-ID), other DOE operations offices, and internal and external INEL organizations are provided by BWID. Program guidance for BWID is directed from OTD through the DOE-ID Technical Program Officer (TPO) and EG\&G Idaho technical program manager (TPM) to the integrated demonstration coordinator (IDC). This structure will be shown in the BWID Strategy Plan.

\subsection{Internal INEL Organization and Responsibilities}

The internal organizational structure is shown in Figure 1.

\subsubsection{Technical Program Officer}

The DOE-ID TPO is responsible for providing guidance and directives for Technical Task Plans (TTPs) in support of BWID. The TPO interfaces directly with the IDC for BWID activities.

\subsubsection{Technical Program Manager}

The TPM is responsible for ensuring that approved INEL TTPs in support of BWID are consistent with the directives and guidance provided by the TPO. The TPM interfaces directly with the IDC for BWID activities. The TPM is responsible for maintaining line management accountability to ensure the activities and tasks defined in the approved TTPs meet BWID requirements, including monthly status reports.

\subsubsection{Integrated Demonstration Coordinator}

The IDC functions as the focal point for contacts and correspondence relative to BWID. The IDC is responsible for ensuring that the BWID programmatic objectives are achieved by recommending technologies and projects to the DOE OTD through DOE-ID for inclusion in BWID and to support other Integrated Demonstrations and Integrated Programs. The IDC oversees technology evaluations and programmatic direction with the assistance of the BWID Program Planning Group (PPG) and the BWID Technical and Academic Review Groups (TARGs). The IDC also functions as the principal interface with other OTD-sponsored Integrated Demonstrations or Integrated Programs. 
BWID Program Planning Group (PPG)

INEL Technical Program Officer (TPO)

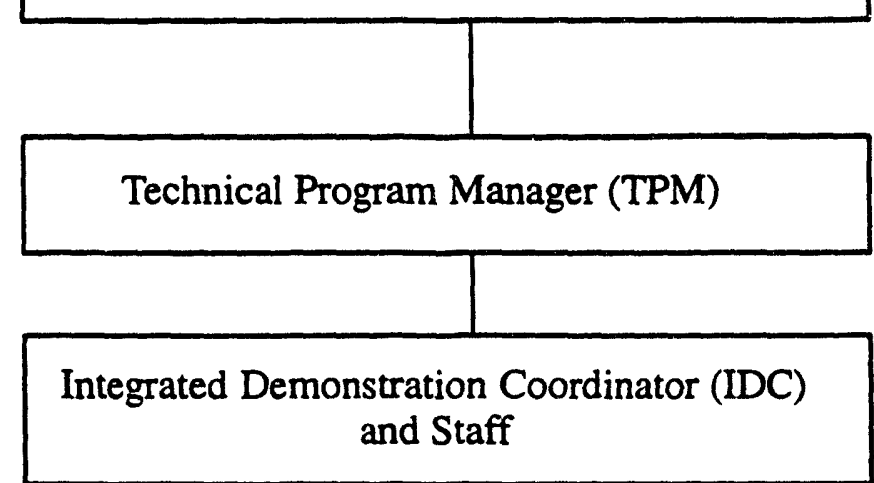

BWID Deployment Program Manager (BDPM)

Technical and Academic Review Group (TARG)

BWID Systems Integration Program Manager (BSIPM)
Technical Development Project Teams (TDPT) Includes-Project/Cost Account Manager (P/CAM) Principal Investigator (PI) \& BWID Technical Liaison (TL)

Figure 1. Internal organization structure. 


\subsubsection{Principal Investigator}

The PIs are technology developers from throughout the DOE complex, industry, and academia developing and demonstrating technologies in support of BWID. The PIs are responsible for ensuring the performance of technical work is of the highest quality and that it is consistent with approved work packages. The PIs are responsible for ensuring industry involvement in the technologies development. The PIs will drive the technology transfer process to ensure the technologies are implemented and commercialized.

\subsubsection{Project/Cost Account Manager}

The project/cost account manager ( $\mathrm{P} / \mathrm{CAM})$ is responsible for ensuring project compliance with DOE and M\&O contractor requirements, DOE orders, and BWID directives. The P/CAM must develop and maintain the baseline for the project; ensure the project meets cost, schedule, and scope objectives; and ensure sponsored work maintains rigor and technical integrity. The P/CAM is responsible for providing weekly and monthly reports to BWID on the project.

\subsubsection{Support Groups}

Collaboration with other sites in the DOE complex is facilitated through the PPG. The PPG is made up of environmental restoration representatives from the INEL and other DOE sites. The PPG evaluates BWID programmatic direction against the needs of the entire DOE complex.

The PPG reviews technical recommendations of the IDC and TARGs to ensure consistency with program objectives. The PPG also reviews recommendations for funding, technology selection, technical direction, analysis, and evaluation of test results. Collaboration with other sites in the DOE complex, other government organizations, and other stakeholders will be facilitated through the BWID PPG. Members of the PPG represent the problem holders as well as technology developers. The PPG is responsible for identifying the end-user, and thus, programmatic needs.

The BWID TARGs consist of technology development experts representing specific areas of expertise pertinent to BWID activities. TARG personnel are drawn from organizations throughout the DOE complex, academic community, industry, and other Federal agencies. The TARGs independently screen and evaluate technological solutions to the various environmental remediation problems identified by the Office of Environmental Restoration and Waste Management.

BWID TARGs provide technical support to the BWID as needed. The TARGs receive programmatic direction from the PPG through the IDC. Additional TARGs may be initiated as necessary to support BWID activities.

\subsubsection{BWID Technical Liaison}

The BWID technical liaisons (TLs) support the IDC. TLs ensure the technical content of BWID work satisfies the high-level objectives of the program and advances the state of the art. TLs work with the PIs to ensure integration between BWID-sponsored projects, communicate closely with PIs to identify potential problems, formulate corrective actions, and serve as a member of technology transfer team to ensure commercialization/implementation of BWID-sponsored technologies. 


\subsubsection{BWID System Integration Program Manager}

The BWID systems integration program manager (BSIPM) is responsible for coordination of BWID systems integration and planning, technology transfer, market assessments, and stakeholder activities. The BSIPM directly supports the IDC. The BSIPM is responsible for ensuring that commercialization and implementation opportunities are achieved, technology integration opportunities are explored, and customer needs are well defined and satisfied.

\subsubsection{BWID Deployment Program Manager}

The BWID deployment program manager (BDPM) is responsible for coordinating BWID technology deployment activities. The BDPM is the primary focal point for participating technologies to be deployed and field demonstrated under BWD. The BDPM is responsible for ensuring that relevant regulatory requirements are satisfied, deployment documentation is completed, testing requirements are defined, BWID demonstration schedules are met, and field activities are performed safely. 


\section{SCHEDULE}

Scheduling activities for a successful demonstration is necessary on two different levels-first to ensure that facilities and operational requirements of the demonstration sites do not interfere with each other, and second to ensure that the various activities within a particular project are properly planned in the appropriate sequence and have sufficient time for successful completion.

Because BWID projects range from paper studies to very complex field demonstrations, scheduling activities vary significantly.

A BWID life-cycle planning guide (see Figure 2) has been developed to assist PIs in the development of critical path schedules required in Section 5C. The guide highlights significant deliverables needed to meet regulatory and operational requirements. Deliverables addressed in this guide include the following:

- $\quad$ TTP

- Technology Preparedness and Status Report

- National Environmental Policy Act (NEPA) documentation (categorical exclusion or environmental assessment)

- Hazard classification documentation (routinely accepted by public, unreviewed safety question, low hazard, moderate hazard, or high hazard)

- Test Plan

- Preparedness/Operational Readiness Review Checklist

- Technology Evaluation Report.

Environmental assessments and safety analysis documents can take several months for approval and should be seriously considered when preparing schedules. Environmental checklists must be submitted for every project, including paper studies or offsite activities. If the activity will occur at another Federal facility, the NEPA documentation must be submitted through that agency. Based on the experiences of EG\&G Idaho professionals, average durations have been included in the guide. 
BWID Life Cycle Planning Guide

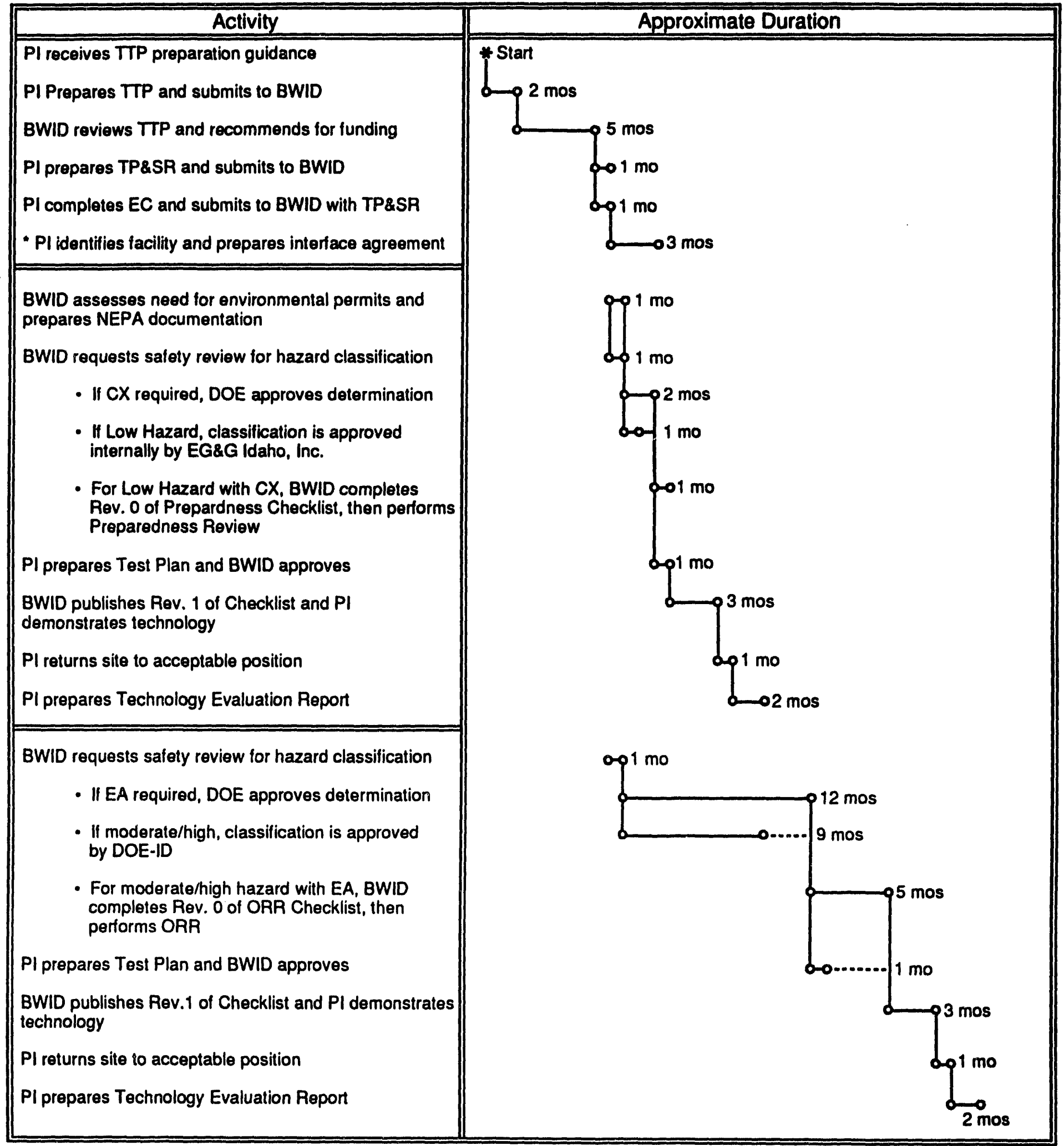

" Facility for demonstration must be identified prior to starting NEPA and safely analysis work

T92 0450

Figure 2. BWID life/cycle planning guide. 


\section{TECHNOLOGY PREPAREDNESS AND STATUS REPORT PREPARATION GUIDANCE}

\subsection{General Guidance}

Prepare a Technology Preparedness and Status Report using the appropriate outline provided in Appendix A. Appendix A-1 is meant for mature technologies ready for a demonstration test. Appendix A-2 is meant for immature technologies needing one or more years of research until mature enough for a field demonstration test and includes the requirement to complete a Technology Commercialization Plan (see Appendix C). Appendix A-3 is meant for paper studies only, where the effort involves no hardware or laboratory tests other than computer software, modeling, or simulation. An explanation for each section is also included in Appendix A. To minimize the time required to generate this report, each PI will be provided a 3.5-inch floppy disk containing the outlines tailored to the specific technology using WordPerfect 5.1. Disks are available for both IBM-compatible and Macintosh computers. If neither are compatible with existing systems, the PI may generate the document from scratch.

When possible, some sections of the outline will be completed by the BWID staff using information from the TTP. The PI may edit these sections to improve the information as required. The PI will complete the remaining sections following the explanations for each section.

\subsection{Preparedness Checklist and Action Plan}

The Preparednes. Checklist and Action Plan (see Appendix B) is a critical part of this document. It serves primarily as the early planning tool for the PI where previous information (Sections 2-6) will primarily support the needs of the BWID management. This checklist can also be used apart from this document to assist in the development of TTPs to ensure adequate consideration has been given to requirements with respect to budget and schedule. Again, the different types of projects will use separate checklists as provided in Appendix B. Appendix B-1 is meant for field demonstration or technology research tasks, both of which involve hardware tests and operations other than computer software or simulations. Appendix B-2 is meant for paper studies where no hardware tests or operations other than computer use for software or simulations will occur. The instructions for filling out that checklist are also included in Appendix B. 


\section{Appendix A}

\section{Technology Prepareuness and Status Report Outline}




\section{Appendix A}

\section{Technology Preparedness and Status Report Outline A-1. FIELD DEMONSTRATION PROJECTS}

COVER PAGE

\section{CONTENTS}

\section{PURPOSE}

The purpose of this document is to provide the BWID deployment team with sufficient information to evaluate preparedness or status of (add technology name. TTP title, and number) through its performance in a field demonstration test. A field demonstration of a technology means that the technology is mature enough to bring it to a field test whereby the technology will be run through a number of test evolutions that simulate the actual operation that it would experience as part of a total waste remediation system. This document will also foster communication between BWID and Environmental Restoration (ER) on the status and plans of this project.

(Note that ER will review the draft Technology Preparedness and Status Report.)

\section{NEED FOR TECHNOLOGY}

To address this issue, the PI must work through the TL or TPM to establish a contact with ER in order to obtain the specific information needed. In addressing this issue the PI specifically should not just repeat the generalities that were used in the original TTP.

Briefly discuss the DOE environmental or operational problem or issue that the technology would address. If possible, state the specific regulatory requirement or the specific provision of the Federal Facility Agreement and Consent Order in question.

Name DOE site(s) and, if possible, the specific facilities that would benefit from the development and application of the proposed technology.

State the type of waste or contaminant or contaminated medium that is targeted by the technology. Mention any other potential DOE applications.

Is it envisioned that the proposed technology will require coordination with any complementary technology(s)? If so, provide a brief description and readiness assessment for the complementary technology(s). 


\section{OBJECTIVE OF DEMONSTRATION}

Briefly state the objective(s) of the demonstration. The high-level objectives are published by BWID every year and should be referred to while developing this section. The PI should not simply rehash the generalities presented in the TTP, but should define very specific goals and test objectives that will become the basis for the Test Plan. That Test Plan will have to be drafted about 6 months after the Technology Preparedness and Status Report (TP\&SR).

\section{TECHNOLOGY DESCRIPTION AND READINESS EVALUATION}

A. Description

Beginning with a process flow diagram, describe the technology process.

Also discuss operating principles of the technology.

Discuss the relationship between the proposed demonstration and the envisioned full-scale operation, in terms of scale and function.

State whether the technology is a system component or a system; explain.

This is not meant to be a total repeat of the TTP. Emphasize what is new and provide more details.

B. Demonstrated Performance

Describe the results of research to date for the proposed technology (i.e., technical maturity). Discuss data obtained, testing results, problem areas, and conclusions. Do not just copy from the TTP. Emphasize what is new.

C. Technology Performance

Compare the proposed technology against the current technology for performing the same function. Discuss why the current technology is not fully adequate. Describe the potential superiority of the proposed technology (i.e., potential performance).

Provide cost savings estimates and justifications for those estimates.

Discuss the envisioned performance (i.e., effectiveness) of the technology in terms of treatment capacity, maximum throughput, useful life expectancy, etc. Discuss the envisioned limitations of the technology (e.g., waste type, waste form, interfering compounds, potential malfunctions, and weather restrictions).

In order to adequately address this item, the PI must work with ER to obtain the necessary information on performance and cost of current technology. 


\section{Regulatory and Public Acceptance of Technology}

Describe regulatory requirements and issues (NEPA; Resource Conservation and Recovery Act; Comprehensive Environmental Response, Compensation, and Liability Act; etc.) as related to the proposed technology demonstration and not the ultimate application of this technology (as was probably done in the TTP, i.e., do not repeat the TTP). Discuss strategies for addressing these issues. Include regulatory strategies for effluent, by-products, and residuals. If applicable, discuss previous resolutions of regulatory issues for related demonstrations of this technology. Also address the hazard classification determination that has been received or that is anticipated.

Discuss any issues of public acceptance related to the demonstration of this technology.

\section{DEMONSTRATION REQUIREMENTS}

\section{A. Location}

Briefly describe where the tasks are to be performed.

\section{B. Organization}

Discuss what organizations will be involved in performing the demonstration (i.e., private sector, universities, and other government agencies). Describe the roles, responsibilities, and interfaces. Also include a description of the PI, program manager, and technical liaison functions and who is serving in that role.

\section{Schedule Requirements}

Provide a schedule for the entire project and indicate the critical path activities required to successfully perform the demonstration.

\section{Data Requirements}

Identify the specific types of data that need to be obtained in the demonstration in order to validate the technology. Discuss the operating parameters, environmental conditions, waste characteristics, and other constraints that need to be satisfied in order to obtain the necessary data.

E. Operational Support Requirements

List the operational, facility, utility, and other support requirements for the demonstration.

\section{PREPAREDNESS CHECKLIST AND ACTION PLAN}

Instructions are provided in Appendix B. 


\section{A-2. RESEARCH PROJECTS}

\section{COVER PAGE}

\section{CONTENTS}

\section{PURPOSE}

The purpose of this document is to provide the BWID deployment team with sufficient information to evaluate preparedness or status of (add technology name. TIP title, and number) as a research project. A technology is considered a research project if its present status and its projected status during this funding period are not and will not be a prototype that can go to the field and be exercised with simulated operations as it is ultimately intended as part of a waste remediation system. This document will also foster communication between BWID and ER on the status and plans of this project.

(Note that ER will review the draft Technology Preparedness and Status Report.)

\section{NEED FOR TECHNOLOGY}

To address this issue the PI must work through the TL or TPM to establish a contact with ER in order to obtain the specific information needed. In addressing this issue, the PI specifically should not just repeat the generalities that were used in the original TTP.

Briefly discuss the DOE environmental or operational problem or issue that the technology would address. If possible, state the specific regulatory requirement or the specific provision of the Federal Facility Agreement and Consent Order in question.

Name DOE site(s) and, if possible, the specific facilities that would benefit from the development and application of the proposed technology.

State the type of waste or contaminant or contaminated medium that is targeted by the technology. Mention any other potential DOE applications.

\section{OBJECTTVE OF RESEARCH}

Briefly state the objective(s) of the research. The high-level objectives are published by BWID every year and should be referred to while developing this section. The PI should provide details and specifics beyond what was presented in the TTP.

\section{TECHNOLOGY DESCRIPTION AND READINESS EVALUATION}

A Description

Describe the technology process, to the degree known. 
Also discuss operating principles of the technology.

State whether the technology is a system component or a system; explain.

This is not meant to be a total repeat of the TTP. Emphasize what is new and provide more details.

B. Demonstrated Performance

Describe the results of research to date for the proposed technology (i.e., technical maturity). Discuss data obtained, testing results, problem areas, and conclusions. Emphasize new information beyond what is covered in the TTP.

C. Technology Performance

Compare the proposed technology against the current technology for performing the same function. Discuss why the current technology is not fully adequate. Describe the potential superiority of the proposed technology (i.e., potential performance).

Discuss the envisioned performance (i.e., effectiveness) of the technology in terms of treatment capacity, maximum throughput, useful life expectancy, etc. Discuss the envisioned limitations of the technology (e.g., waste type, waste form, interfering compounds, potential malfunctions, and weather restrictions).

In order to adequately address this item, the PI must work with ER to obtain the necessary information on performance and cost of current technology.

D. Regulatory and Public Acceptance of Technology

Describe regulatory requirements and issues (NEPA, Resource Conservation and Recovery Act; Comprehensive Environmental Response, Compensation, and Liability Act; etc.) as related to the proposed technology development and not the ultimate application of this technology (as was probably done in the TTP (i.e., do not repeat the TTP). Discuss strategies for addressing these issues. Include regulatory strategies for effluent, by-products, and residuals. If applicable, discuss previous resolutions of regulatory issues for related demonstrations of this technology. Also address the hazard classification determination that has been received or that is anticipated.

Discuss any issues of public acceptance related to the technology development and not its application.

E. Readiness for Demonstration

Discuss the readiness of the technology to proceed to the BWID demonstration state (i.e., implementability). Emphasize what is new beyond what might have been presented in the TTP. 


\section{REQUIREMENTS}

A. Location

Briefly describe where the tasks are to be performed.

B. Organization

Discuss what organizations will be involved in performing the activities (i.e., private sector, universities, and other government agencies). Describe the roles, responsibilities, and interfaces. Also include a description of the PI, program manager, and technical liaison functions and who is serving in that role.

C. Schedule Requirements

Provide a schedule for the entire project and indicate the critical path activities required to successfully perform the activities.

D. Data Requirements

Identify the specific types of data that need to be obtained in the tests in order to validate the technology. Discuss the operating parameters, environmental conditions, waste characteristics, and other constraints that need to be satisfied in order to obtain the necessary data. Emphasize what is new as to what was discussed in the TTP.

E. Operational Support Requirements

List the operational, facility, utility, and other support requirements for the tests.

F. Technology Commercialization

Complete the BWID Technology Commercialization Guide (see Appendix C).

\section{PREPAREDNESS CHECKLIST AND ACTION PLAN}

Instructions are provided in Appendix B. 


\section{A-3. PAPER STUDY PROJECTS}

\section{COVER PAGE}

\section{CONTENTS}

\section{PURPOSE}

The purpose of this document is to provide the BWID deployment team with sufficient information to evaluate status of (add technology name. TTP title, and number) as a paper study. A paper study is a project that involves no laboratory testing or hardware operation, except for the use of computers for modeling, simulation, or software development. This document will also foster communication between BWID and ER on the status and plans of this project.

(Note that ER will review the draft Technology Preparedness and Status Report.)

\section{NEED FOR STUDY}

Briefly discuss the need for performing the study in terms of benefit to BWID and ER. To address this issue, the PI must work through the TL or TPM to establish a contact with ER in order to obtain the specific information needed. In addressing this issue, the PI specifically should not just repeat the generalities that were used in the original TTP.

\section{OBJECTIVE OF STUDY}

Briefly state the objective(s) of the study. The high-level objectives are published by BWID every year and should be referred to while developing this section. The PI should provide details and specifics beyond what was presented in the TTP.

\section{DESCRIPTION}

\section{A. Description}

Describe the study and how the results of the study will be used.

B. Regulatory and Public Acceptance of Technology

Describe regulatory requirements and issues (NEPA, Resource Conservation and Recovery Act; Comprehensive Environmental Response, Compensation, and Liability Act; etc.) that will be addressed related to the performing the proposed study and not the ultimate application of this technology (as was probably done in the TTP, i.e., do not rehash the TTP). Discuss strategies for addressing these issues. Note that NEPA is still required for a paper study. 


\section{Readiness for Implementation}

Discuss how and when the results of the will be used. If the study relates to the feasibility of a specific technology, provide an estimate of when that technology could be demonstrated if the study concludes the technology is worth pursuing. Emphasize what is new beyond what may have been presented in the TTP.

\section{REQUIREMENTS}

\section{A. Location}

Briefly describe where the study will be performed.

B. Organization

Discuss what organizations will be involved in performing the activities (i.e., private sector, universities, and other government agencies). Describe the roles, responsibilities, and interfaces. Also include a description of the PI, program manager, and technical liaison functions and who is serving in that role.

C. Schedule Requirements

Provide a schedule for the entire project and indicate the critical path activities required to successfully perform the activities.

\section{PREPAREDNESS CHECKLIST AND ACTION PLAN}

Instructions are provided in Appendix B. 


\section{Appendix B}

Preparedness Checklist and Action Plan

B-1 


\section{Appendix B}

\section{Preparedness Checklist and Action Plan}

The principal investigator (PI) transmits the status report and initial Preparedness Checklist and Action Plan (PC\&AP) via letter to the BWID deployment program manager. The letter signifies that requirements of the PC\&AP are current as of the transmittal date and identifies specific action completed or required.

The checklist is complete when all items are either "yes" or "NA". At that time, a PC\&AP with individual signatures approving each requirement action will be completed. Approval signatures are provided in the following manner:

1. Those items identified in Sections 1 and 2 of the PC\&AP will be signed by either the BWID Facility Representative or the BWID Operations Representative. Section 3 can be approved by the above or the BWID deployment program manager.

2. Those items identified as BWID Safety, Quality, and Environmental will be signed by the individual cognizant professional matrixed to BWID.

3. Those items identified as EPA, Quality, or Safety will be signed by the valid department cognizant professionals to provide required independent verification.

The PC\&AP is complete when the BWID deployment program manager signs the checklist acknowledgment. A letter with the attached checklist is then issued to the PI by the BWID integrated demonstration coordinator granting approval to commence testing or continue the research. 


\section{Appendix B-1}

Field Demonstration and Research Projects

B-5 


\section{BURIED WASTE INTEGRATED DEMONSTRATION PREPAREDNESS CHECKLIST AND ACTION PLAN (Demonstration and Research Projects)}

TTP Title: TTP No.

PI Name:

Phone: ( )

$F a x()$

PI Instructions: Input answer to questions using $\mathrm{Y}=$ yes, $\mathrm{N}=$ not addressed yet, and $\mathrm{NA}=$ not applicable. If response is $\mathrm{N}$, enter planned completion date in column 3. If response is NA, complete justification section of column 3 . This should be periodically updated. *Items must have either $\mathrm{Y}$ or $\mathrm{N}$.

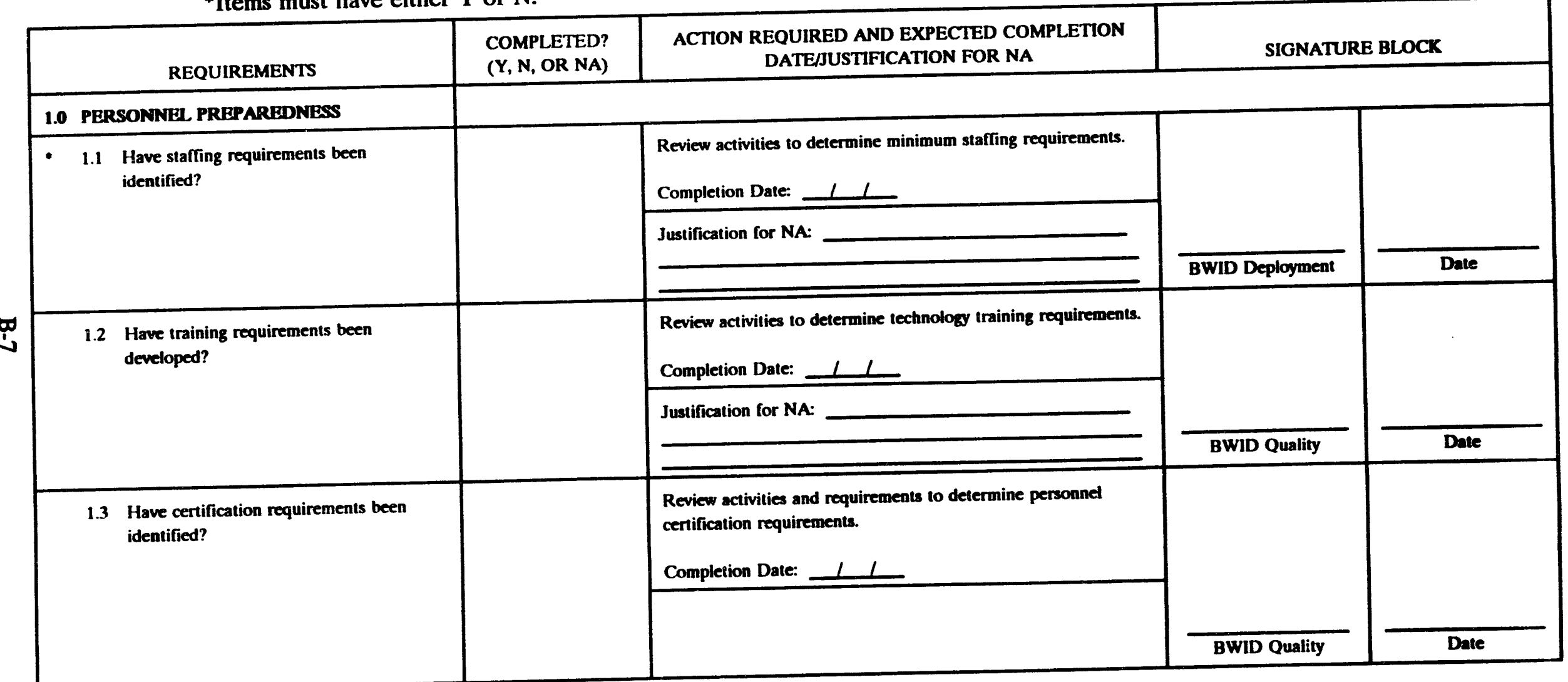




\section{BURIED WASTE INTEGRATED DEMONSTRATION \\ PREPAREDNESS CHECKLIST AND ACTION PLAN \\ (Demonstration and Research Projects)}

TTP No.:

PI Instructions: Input answer to questions using $\mathrm{Y}=$ yes, $\mathrm{N}=$ not addressed yet, and $\mathrm{NA}=$ not applicable. If response is $\mathrm{N}$, enter planned completion date in column 3 . If response is NA, complete justification section of column 3. This should be periodically updated. *Items must have either $\mathrm{Y}$ or $\mathrm{N}$.

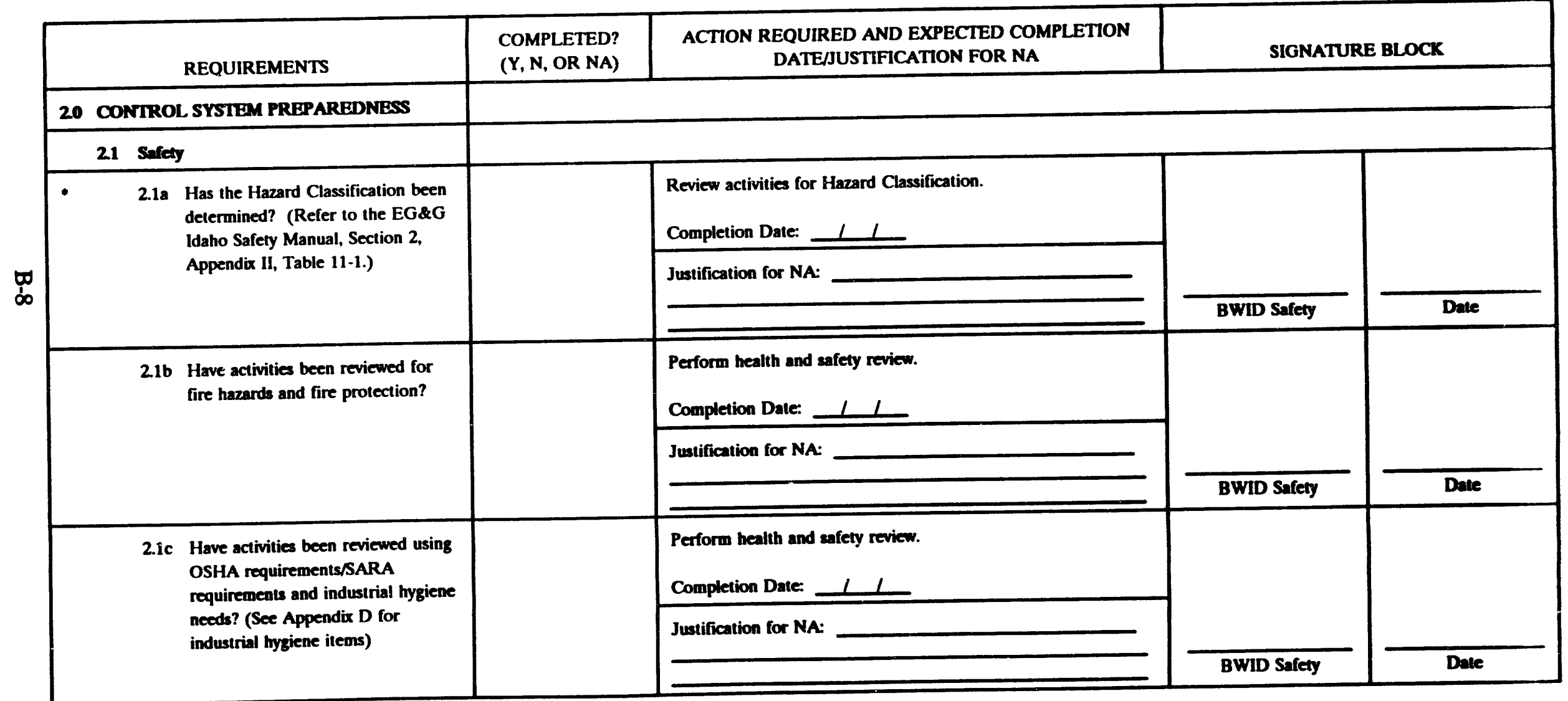




\section{BURIED WASTE INTEGRATED DEMONSTRATION PREPAREDNESS CHECKLIST AND ACTION PLAN (Demonstration and Research Projects)}

TTP No:

PI Instructions: Input answer to questions using $\mathrm{Y}=$ yes, $\mathrm{N}=$ not addressed yet, and $\mathrm{NA}=$ not applicable. If response is $\mathrm{N}$, enter planned completion date in column 3 . If response is $\mathrm{NA}$, complete justification section of column 3 . This should be periodically updated. ${ }^{*}$ Items must have either $\mathrm{Y}$ or $\mathrm{N}$.

\begin{tabular}{|c|c|c|c|c|c|c|}
\hline \multicolumn{3}{|r|}{ REQUIREMENTS } & $\begin{array}{l}\text { COMPLETED? } \\
(\mathrm{Y}, \mathrm{N}, \text { OR NA) }\end{array}$ & $\begin{array}{l}\text { ACTION REQUIRED AND EXPECTED COMPLETION } \\
\text { DATE/JUSTIFICATION FOR NA } \\
\end{array}$ & \multicolumn{2}{|c|}{ SIGNATURE BLOCK } \\
\hline \multicolumn{7}{|c|}{$\begin{array}{c}\text { REQUIREMENTS } \\
20 \text { CONIROL SYSTEM PREPAREDNESS }\end{array}$} \\
\hline \multicolumn{3}{|c|}{21 Sifety } & & & & \\
\hline \multirow{3}{*}{\multicolumn{3}{|c|}{$\begin{array}{l}\text { 2.1d Have activities been reviewed to } \\
\text { determine need for } \\
\text { decontamination capabilities } \\
\text { (equipment and personnel)? }\end{array}$}} & & $\begin{array}{l}\text { Perform health and safety review. } \\
\text { Completion Date: }\end{array}$ & & \\
\hline & & & & Justification for NA: & & \\
\hline & & & & & BWID Safety & Dale \\
\hline & \multirow{3}{*}{\multicolumn{2}{|c|}{$\begin{array}{l}\text { Have all MSDSs been forwarded to } \\
\text { the PI and BWID deployment PM? }\end{array}$}} & & $\begin{array}{l}\text { Forward MSDSs to deployment PM. } \\
\text { Completion Date: } 11\end{array}$ & \multirow{3}{*}{ BWID Safety } & \\
\hline & & & & Justification for NA: & & \\
\hline & & & & & & Dale \\
\hline $22 P$ & \multicolumn{2}{|c|}{ Prooodures } & & & & \\
\hline & \multirow{3}{*}{\multicolumn{2}{|c|}{$\begin{array}{l}\text { Have project procedures been } \\
\text { identified? }\end{array}$}} & & $\begin{array}{l}\text { Review activities to determine what procedures will be required } \\
\text { to conduct demonstration. } \\
\text { Completion Date: }\end{array}$ & & \\
\hline & & & & Justification for NA: & & \\
\hline & & & & $\longrightarrow$ & BWID Quality & Date \\
\hline
\end{tabular}




\section{BURIED WASTE INTEGRATED DEMONSTRATION PREPAREDNESS CHECKLIST AND ACTION PLAN (Demonstration and Research Projects)}

TTP No:

PI Instructions: Input answer to questions using $\mathrm{Y}=$ yes, $\mathrm{N}=$ not addressed yet, and $\mathrm{NA}=$ not applicable. If response is $\mathrm{N}$, enter planned completion date in column 3. If response is NA, complete justification section of column 3 . This should be periodically updated. *Items must have either $\mathrm{Y}$ or $\mathrm{N}$.

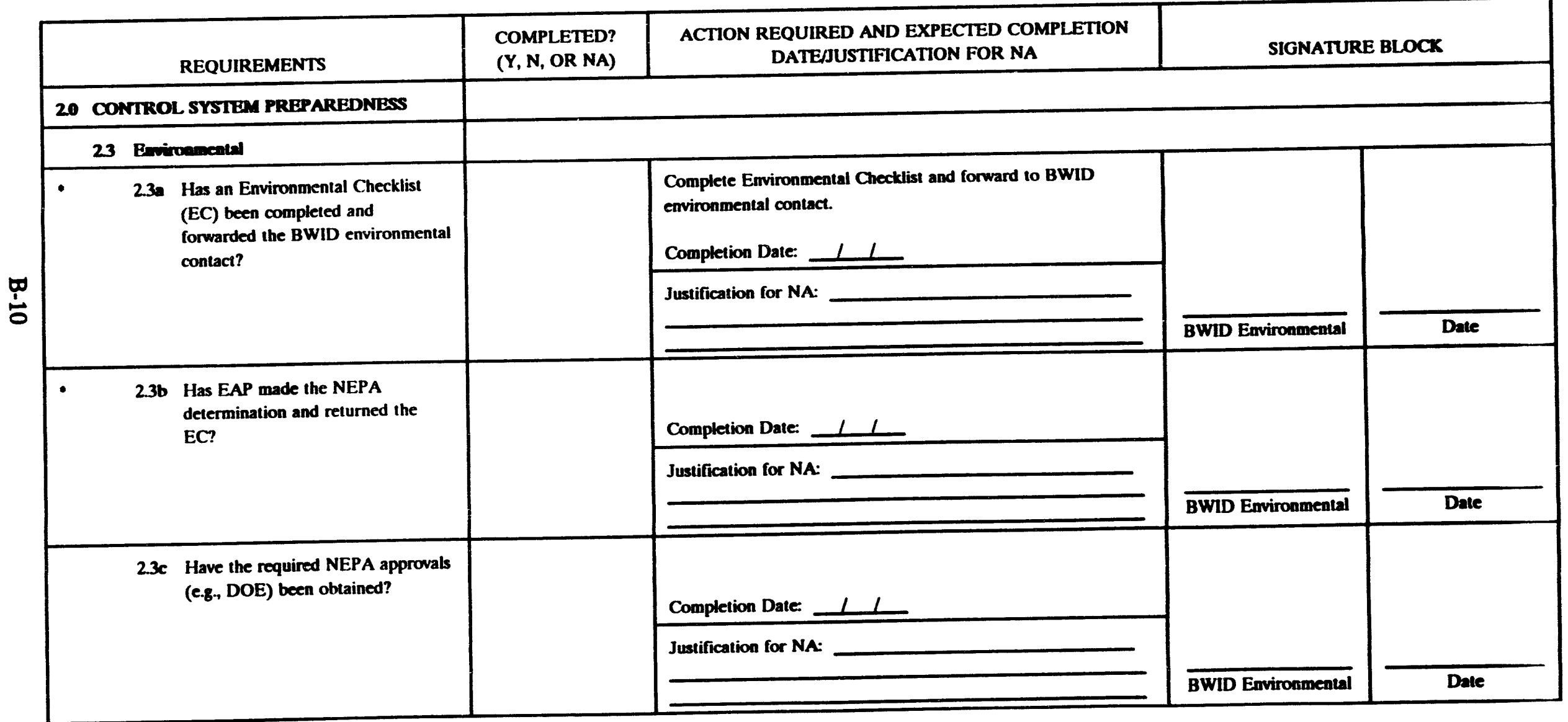




\section{BURIED WASTE INTEGRATED DEMONSTRATION PREPAREDNESS CHECKLIST AND ACTION PLAN (Demonstration and Research Projects)}

TTP No:

PI Instructions: Input answer to questions using $\mathrm{Y}=$ yes, $\mathrm{N}=$ not addressed yet, and $\mathrm{NA}=$ not applicable. If response is $\mathrm{N}$, enter planned in 3 . If response is NA, complete justification section of column 3 . This should be periodically updated. *Items must have either $\mathrm{Y}$ or $\mathrm{N}$.

\begin{tabular}{|c|c|c|c|c|c|}
\hline \multicolumn{2}{|r|}{ REQUIREMENTS } & $\begin{array}{l}\text { COMPLETED? } \\
(\mathrm{Y}, \mathrm{N}, \text { OR NA) }\end{array}$ & $\begin{array}{l}\text { ACTION REQUIRED AND EXPECTED COMPLETION } \\
\text { DATE/JUSTIFICATION FOR NA } \\
\end{array}$ & \multicolumn{2}{|c|}{ SIGNATURE BLOCK } \\
\hline \multicolumn{6}{|c|}{$\begin{array}{c}\text { REQUIREMENTS } \\
20 \text { CONTROL SYSTEM PREPAREDNESS }\end{array}$} \\
\hline \multicolumn{2}{|c|}{ Environmental (continuod) } & & & & \\
\hline \multirow{4}{*}{\multicolumn{2}{|c|}{$\begin{array}{l}\text { 2.3d Have the conditions (e.g.. permits) } \\
\text { specified on the completed NEPA } \\
\text { EC been met? }\end{array}$}} & & Meet conditions on EC. & & \\
\hline & & & Completion Date: 11 & & \\
\hline & & & Justification for NA: & & \\
\hline & & & $\longrightarrow$ & BWID Environmental & Dale \\
\hline \multirow[t]{2}{*}{$2.3 e$} & \multirow[t]{2}{*}{$\begin{array}{l}\text { Have activities been reviewed to } \\
\text { determine need for spill prevention } \\
\text { measures? }\end{array}$} & & $\begin{array}{l}\text { Review activities to determine the need for spill prevention } \\
\text { measures. } \\
\text { Completion Date: }\end{array}$ & \multirow{2}{*}{ BWID Environmental } & \\
\hline & & & Justification for NA: & & \\
\hline \multirow[t]{3}{*}{$2.3 \mathrm{f}$} & \multirow[t]{3}{*}{$\begin{array}{l}\text { Have potential spill hazards been } \\
\text { identified to the BWID deployment } \\
\text { PM? }\end{array}$} & & $\begin{array}{l}\text { Send letter to deployment PM. } \\
\text { Completion Date: } 11\end{array}$ & \multirow[b]{3}{*}{$\overline{\text { BWID Environmental }}$} & \\
\hline & & & Justification for NA: & & \\
\hline & & & $\longrightarrow$ & & Dare \\
\hline
\end{tabular}




\section{BURIED WASTE INTEGRATED DEMONSTRATION PREPAREDNESS CHECKLIST AND ACTION PLAN (Demonstration and Research Projects)}

TTP Na:

PI Instructions: Input answer to questions using $\mathrm{Y}=$ yes, $\mathrm{N}=$ not addressed yet, and $\mathrm{NA}=$ not applicable. If response is $\mathrm{N}$, enter planned completion date in column 3 . If response is NA, complete justification section of column 3 . This should be periodically updated. *Items must have either $\mathrm{Y}$ or $\mathrm{N}$.

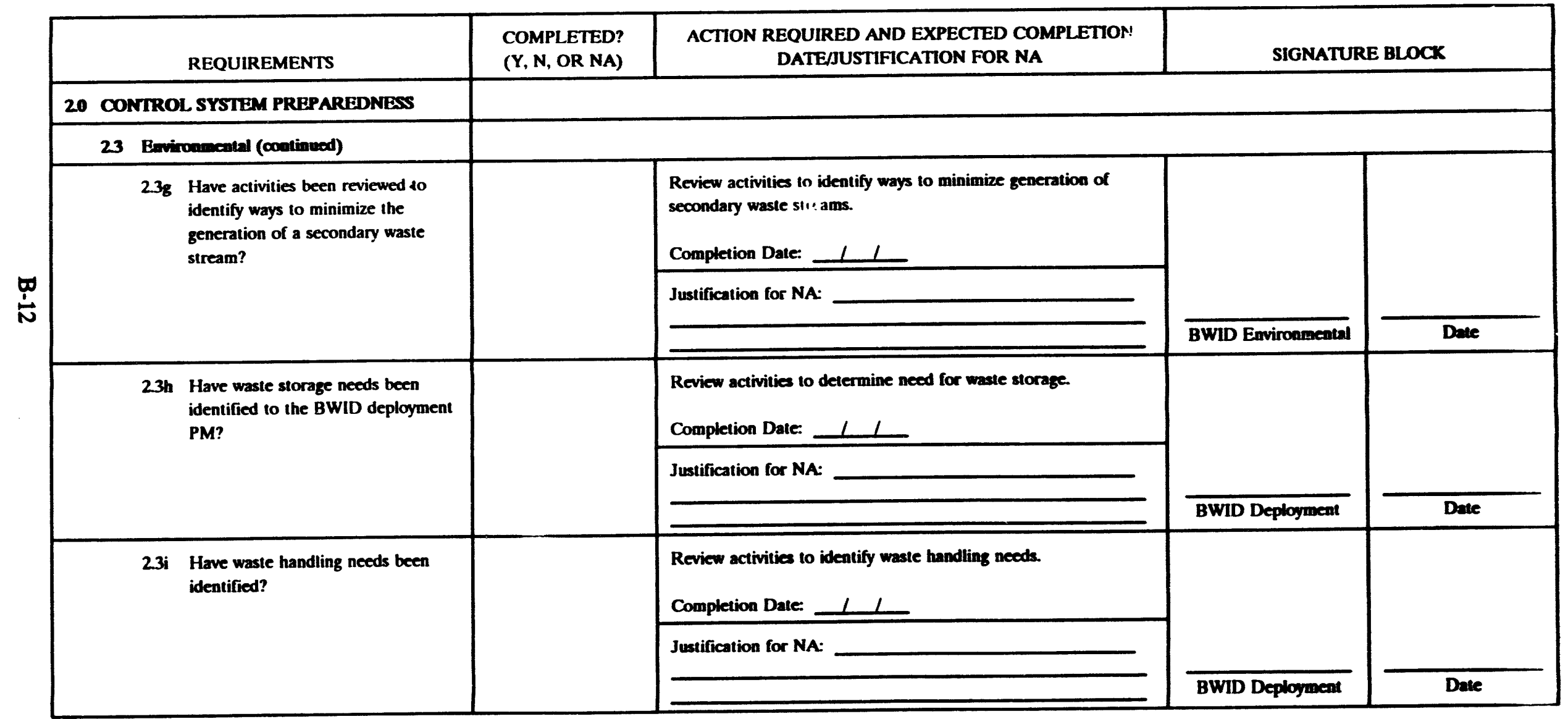




\section{BURIED WASTE INTEGRATED DEMONSTRATION PREPAREDNESS CHECKLIST AND ACTION PLAN (Demonstration and Research Projects)}

TTP No:

PI Instructions: Input answer to questions using $\mathrm{Y}=$ yes, $\mathrm{N}=$ not addressed yet, and $\mathrm{NA}=$ not applicable. If response is $\mathrm{N}$, enter planned completion date in column 3 . If response is NA, complete justification section of column 3 . This should be periodically updated. *Items must have either $\mathrm{Y}$ or $\mathrm{N}$.

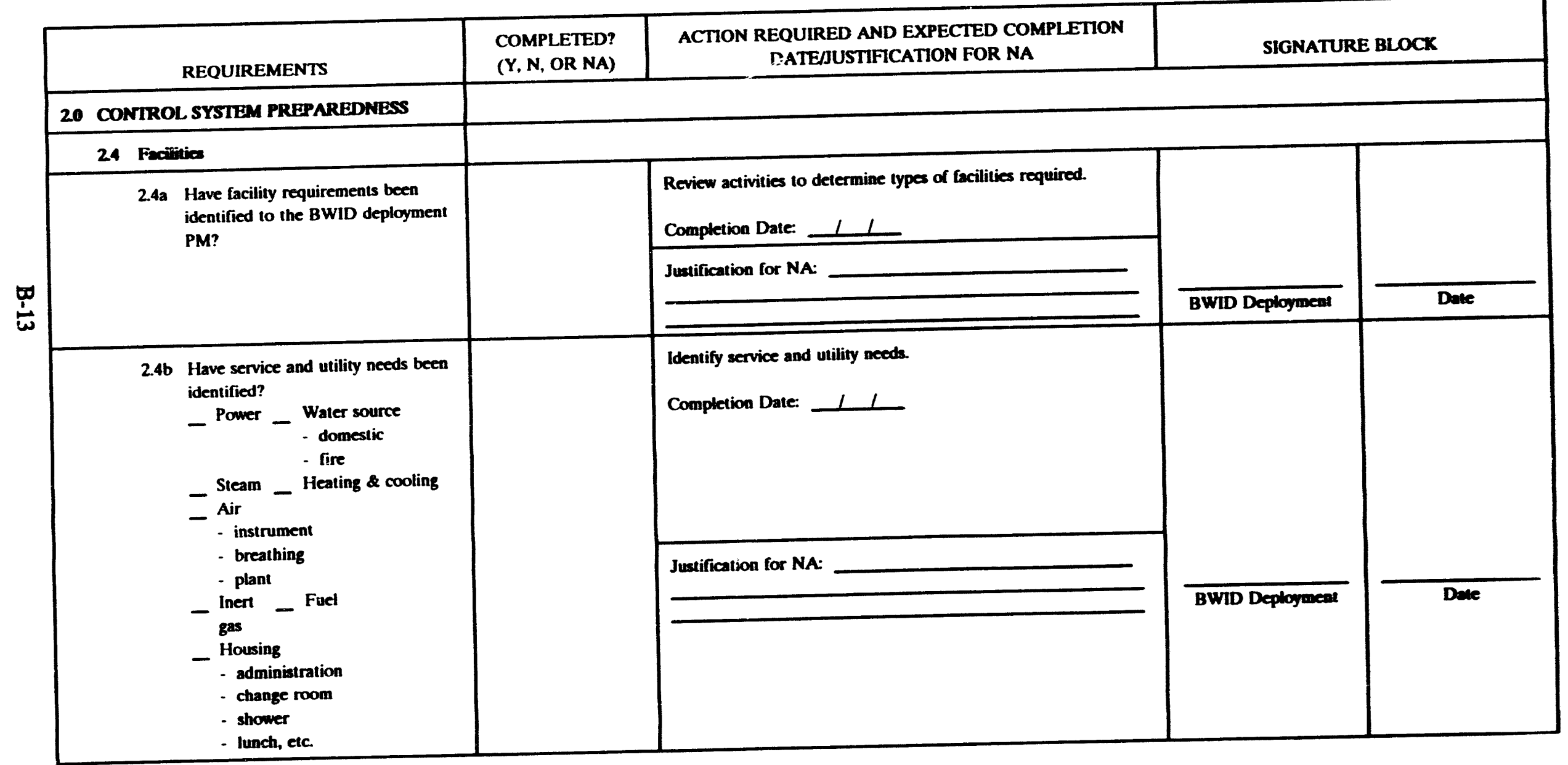




\section{BURIED WASTE INTEGRATED DEMONSTRATION PREPAREDNESS CHECKLIST AND ACTION PLAN (Demonstration and Research Projects)}

TTP No.:

PI Instructions: Input answer to questions using $\mathrm{Y}=$ yes, $\mathrm{N}=$ not addressed yet, and $\mathrm{NA}=$ not applicable. If response is $\mathrm{N}$, enter planned completion date in column 3 . If response is NA, complete justification section of column 3 . This should be periodically updated. *Items must have either $\mathrm{Y}$ or $\mathrm{N}$.

\begin{tabular}{|c|c|c|c|c|c|c|}
\hline & & REQUIREMENTS & $\begin{array}{l}\text { COMPLETED? } \\
(\mathrm{Y}, \mathrm{N}, \text { OR NA) } \\
\end{array}$ & $\begin{array}{l}\text { ACTION REQUIRED AND EXPECTED COMPLETION } \\
\text { DATEAUSTIFICATION FOR NA } \\
\end{array}$ & \multicolumn{2}{|c|}{ SIGNATURE BLOCK } \\
\hline \multicolumn{7}{|c|}{20 CONIROL SYSTEM PREPAREDNESS } \\
\hline \multicolumn{7}{|c|}{25 Omily } \\
\hline \multirow[t]{3}{*}{ - } & \multirow[t]{3}{*}{$2.5 \mathrm{a}$} & \multirow{3}{*}{$\begin{array}{l}\text { Is a document control system in } \\
\text { place? (Should be addressed in the } \\
\text { Quality Plan or Project } \\
\text { Management Ptan.) }\end{array}$} & & $\begin{array}{l}\text { Developfimplement control system. } \\
\text { Completion Date: } 11\end{array}$ & & \\
\hline & & & & Justification for NA: & & \\
\hline & & & & & BWID Qualiny & Dane \\
\hline \multirow[t]{3}{*}{ - } & \multirow[t]{3}{*}{$2.5 b$} & \multirow{3}{*}{$\begin{array}{l}\text { Is a self-asseasment system in } \\
\text { place? (Should be addressed in the } \\
\text { Project Management Ptan or other } \\
\text { project document.) }\end{array}$} & & $\begin{array}{l}\text { Developfimplement a setf-emesement sysem. } \\
\text { Completion Date. } 11\end{array}$ & & \\
\hline & & & & Justification for NA: & & \\
\hline & & & & & BWID Ouatiny & Dene \\
\hline \multirow[t]{3}{*}{ - } & \multirow[t]{3}{*}{$25 \mathrm{c}$} & \multirow{3}{*}{$\begin{array}{l}\text { Is a deficiency documentation } \\
\text { system in place? (Should be } \\
\text { addressed in the Quality Ptan or } \\
\text { Project Management Plan.) }\end{array}$} & & $\begin{array}{l}\text { Develop/implement deficiency documentation system. } \\
\text { Completion Date } 11\end{array}$ & & \\
\hline & & & & Justification for NA: & & \\
\hline & & & & & BWID Quality & Dere \\
\hline
\end{tabular}




\section{BURIED WASTE INTEGRATED DEMONSTRATION PREPAREDNESS CHECKLIST AND ACTION PLAN \\ (Demonstration and Research Projects)}

Page 9 of 15

TTP No:

PI Instructions: Input answer to questions using $Y=$ yes, $\mathbf{N}=$ not addressed yet, and $N A=$ not applicable. If response is $N$, enter planned completion date in column 3. If response is NA, complete justification section of column 3. This should be periodically updated. *Items must have either $\mathrm{Y}$ or $\mathrm{N}$.

\begin{tabular}{|c|c|c|c|c|c|c|}
\hline & & REQUIREMENTS & $\begin{array}{l}\text { COMPLETED? } \\
(\mathbf{Y}, \mathbf{N}, \text { OR NA) }\end{array}$ & $\begin{array}{l}\text { ACTION REOUIRED AND EXPECTED COMPLETION } \\
\text { DATEMUSTIFICATION FOR NA }\end{array}$ & \multicolumn{2}{|c|}{ SIGNATURE BLOCK } \\
\hline \multicolumn{7}{|c|}{20 CONTROL. SYSTEM MREPAREDNESS } \\
\hline \multicolumn{7}{|c|}{25 Omely (cominuod) } \\
\hline \multirow[t]{3}{*}{ - } & & \multirow[t]{3}{*}{$\begin{array}{l}\text { Will samples be taken? If yes, take } \\
\text { action. }\end{array}$} & & $\begin{array}{l}\text { Develop sampling and anatysis phan. } \\
\text { Completion Date: } 11\end{array}$ & & \\
\hline & & & & Justificanion for NA: & & \\
\hline & & & & & BWID Qmality & Dene \\
\hline & \multirow[t]{3}{*}{$25 e$} & \multirow{3}{*}{$\begin{array}{l}\text { Have process control activities been } \\
\text { developed? (This includes items } \\
\text { such as welding and nondestructive } \\
\text { ecaminations.) }\end{array}$} & & $\begin{array}{l}\text { Developimplement process controte. } \\
\text { Completion Date } 11\end{array}$ & & \\
\hline & & & & Justification for NA: & & \\
\hline & & & & & BWhid Quatity & Dene \\
\hline \multirow[t]{3}{*}{ • } & \multirow[t]{3}{*}{258} & \multirow{3}{*}{$\begin{array}{l}\text { Is a records management system in } \\
\text { place? (Should be addressed in } \\
\text { Quality Ptan or Project } \\
\text { Management Plan.) }\end{array}$} & & $\begin{array}{l}\text { Develophimplement records mangement sydem. } \\
\text { Completion Date } 11\end{array}$ & & \\
\hline & & & & Justification for NA: & & \\
\hline & & & & & BWID Oantity & Dene \\
\hline
\end{tabular}




\section{BURIED WASTE INTEGRATED DEMONSTRATION PREPAREDNESS CHECKLIST AND ACTION PLAN (Demonstration and Research Projects)}

TIP No:

PI Instructions: Input answer to questions using $\mathrm{Y}=$ yes, $\mathrm{N}=$ not addressed yet, and $\mathrm{NA}=$ not applicable. If response is $\mathrm{N}$, enter planned completion date in column 3. If response is NA, complete justification section of column 3. This should be periodically updated. *Items must have either $\mathrm{Y}$ or $\mathrm{N}$.

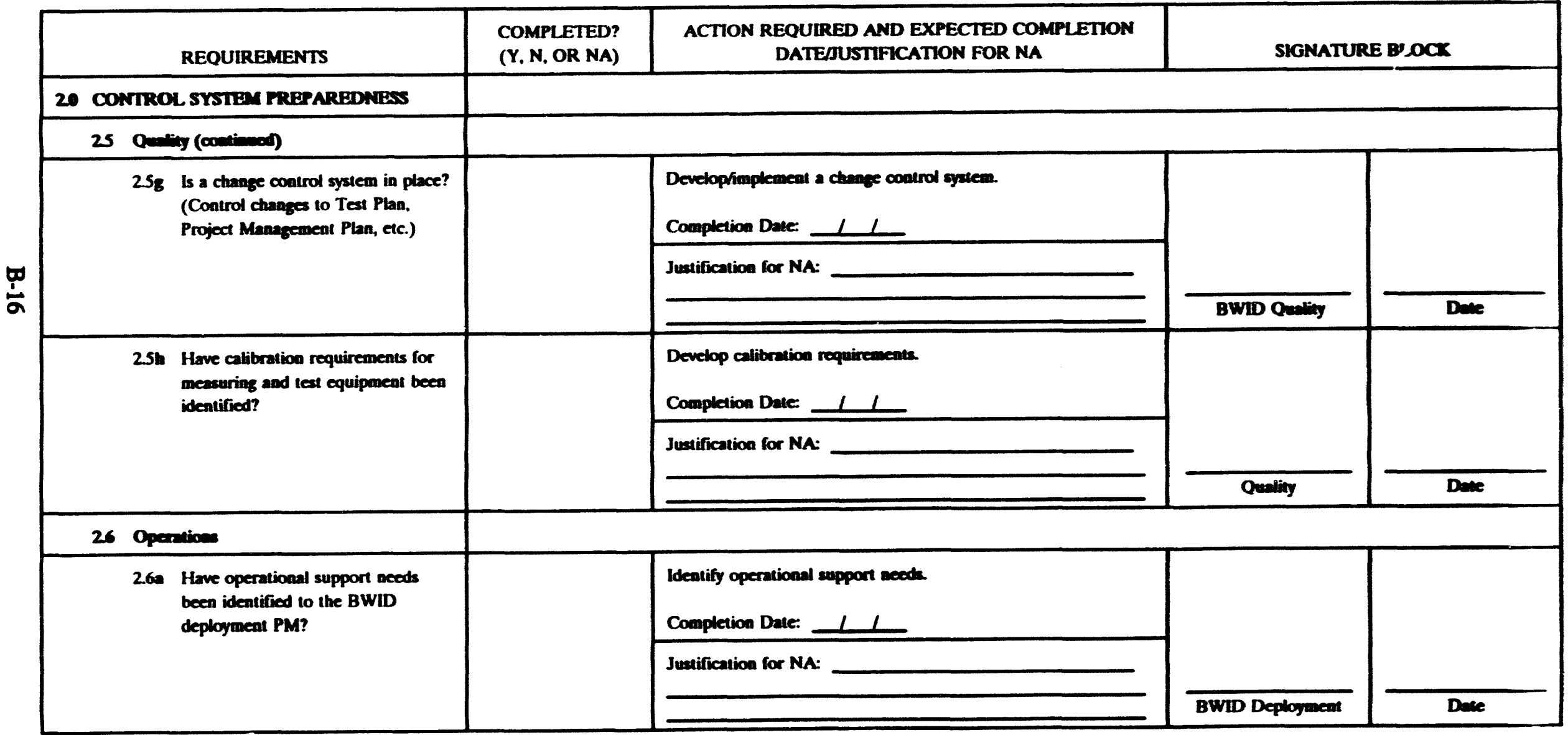




\section{BURIED WASTE INTEGRATED DEMONSTRATION PREPAREDNESS CHECKLIST AND ACTION PLAN (Demonstration and Research Projects)}

TTP No.:

PI Instructions: Input answer to questions using $\mathrm{Y}=$ yes, $\mathrm{N}=$ not addressed yet, and $\mathrm{NA}=$ not applicable. If response is $\mathrm{N}$, enter planned completion date in column 3 . If response is NA, complete justification section of column 3 . This should be periodically updated. *Items must have either $\mathrm{Y}$ or $\mathrm{N}$.

\begin{tabular}{|c|c|c|c|c|c|}
\hline & REQUIREMENTS & $\begin{array}{l}\text { COMPLETED? } \\
\text { (Y, N, OR NA) }\end{array}$ & $\begin{array}{l}\text { ACTION REQUIRED AND EXPECTED COMPLETION } \\
\text { DATEJUSTIFICATION FOR NA }\end{array}$ & \multicolumn{2}{|c|}{ SIGNATURE BLOCK } \\
\hline \multicolumn{6}{|c|}{3.0 HARDWARE PREPAREDNESS } \\
\hline \multirow[t]{3}{*}{3.1} & \multirow[t]{3}{*}{$\begin{array}{l}\text { Has required equipment specifications } \\
\text { been defined? }\end{array}$} & & $\begin{array}{l}\text { Define equipment specifications. } \\
\text { Completion Date: }\end{array}$ & \multirow[b]{3}{*}{ BWID Deployment } & \\
\hline & & & Justification for NA: & & \\
\hline & & & & & Date \\
\hline \multicolumn{2}{|r|}{$\begin{array}{l}\text { 3.2 Has required equipment been identified? } \\
\text { Note: If hoisting and rigging are imolved, } \\
\text { completed Appendix E checklist. If } \\
\text { drilling equipment is to be used, see the } \\
\text { DOE Drilling Manual. }\end{array}$} & & 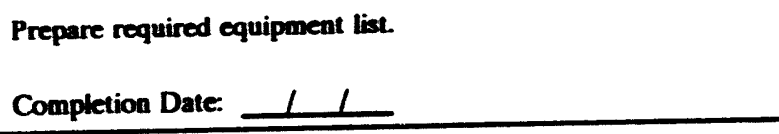 & & \\
\hline & & & Identify noscible contraction. & \multirow{4}{*}{ BWID Deployment } & \\
\hline \multirow{3}{*}{3.3} & \multirow{3}{*}{ Has a contractor been identified? } & & Completion Date: 11 & & \\
\hline & & & Justification for NA: & & \\
\hline & & & & & Date \\
\hline
\end{tabular}




\section{BURIED WASTE INTEGRATED DEMONSTRATION PREPAREDNESS CHECKLIST AND ACTION PLAN (Demonstration and Research Projects)}

TTP No.:

PI Instructions: Input answer to questions using $\mathrm{Y}=$ yes, $\mathrm{N}=$ not addressed yet, and $\mathrm{NA}=$ not applicable. If response is $\mathrm{N}$, enter planned completion date in column 3 . If response is NA, complete justification section of column 3 . This should be periodically updated.

*Items must have either $\mathrm{Y}$ or $\mathrm{N}$.

\begin{tabular}{|c|c|c|c|c|}
\hline REQUIREMENTS & $\begin{array}{l}\text { COMPLETED? } \\
(\mathrm{Y}, \mathrm{N}, \mathrm{OR} \text { NA) } \\
\end{array}$ & $\begin{array}{l}\text { ACTION REQUIRED AND EXPECTED COMPLETION } \\
\text { DATE/JUSTIFICATION FOR NA } \\
\end{array}$ & \multicolumn{2}{|c|}{ SIGNATURE BLOCK } \\
\hline \multicolumn{5}{|l|}{30 HARDWARE PREPAREDNESS } \\
\hline \multirow[t]{3}{*}{ 3.4 Has the design review been completed? } & & $\begin{array}{l}\text { Schedule design review. } \\
\text { Completion Date: } 11\end{array}$ & \multirow[b]{3}{*}{ BWID Deployment } & \\
\hline & & Justification for NA: & & \\
\hline & & & & Date \\
\hline \multirow[t]{3}{*}{ 3.5 Have contracts been completed? } & & Complete contracts. & & \\
\hline & & Completion Date: 11 & & \\
\hline & & Justification for NA: & BWID Deployment & Dave \\
\hline \multirow[t]{4}{*}{ 3.6 Have vendor manuals been provided? } & & Oblain required vendor manuals. & & \\
\hline & & Completion Date: 11 & & \\
\hline & & Justification for NA: & & \\
\hline & & - & BWID Deployment & Dale \\
\hline
\end{tabular}




\section{BURIED WASTE INTEGRATED DEMONSTRATION \\ PREPAREDNESS CHECKLIST AND ACTION PLAN \\ (Demonstration and Research Projects)}

Page 13 of 15

TTP No.:

PI Instructions: Input answer to questions using $\mathrm{Y}=$ yes, $\mathrm{N}=$ not addressed yet, and $\mathrm{NA}=$ not applicable. If response is $\mathrm{N}$, enter planned completion date in column 3 . If response is NA, complete justification section of column 3 . This should be periodically updated. *Items must have either $\mathrm{Y}$ or $\mathrm{N}$.

\begin{tabular}{|c|c|c|c|c|c|}
\hline & REQUIREMENTS & $\begin{array}{l}\text { COMPLETED? } \\
(Y, N, \text { OR NA) } \\
\end{array}$ & $\begin{array}{l}\text { ACTION REQUIRED AND EXPECTED COMPLETION } \\
\text { DATE/JUSTIFICATION FOR NA }\end{array}$ & \multicolumn{2}{|c|}{ SIGNATURE BLOCK } \\
\hline \multicolumn{6}{|c|}{ 3.0 HARDWARE PREPARRBDNESS } \\
\hline \multirow{4}{*}{\multicolumn{2}{|c|}{ 3.7 Have as-buill drawings been completed? }} & & Complete as-built drawings. & & \\
\hline & & & Completion Date: 11 & & \\
\hline & & & Iustification for NA: & & \\
\hline & & & & BWID Deployment & Date \\
\hline \multirow[t]{3}{*}{3.8 h } & \multirow[t]{3}{*}{$\begin{array}{l}\text { Have acceptance lests been conducted on } \\
\text { hardware? }\end{array}$} & & $\begin{array}{l}\text { Complete acceptance lests. } \\
\text { Completion Date: } 11\end{array}$ & \multirow[b]{3}{*}{ BWID Deployment } & \\
\hline & & & Justification for NA: & & \\
\hline & & & & & Dale \\
\hline \multirow[t]{3}{*}{3.9} & \multirow[t]{3}{*}{$\begin{array}{l}\text { Have required spare parts theen } \\
\text { identified? }\end{array}$} & & 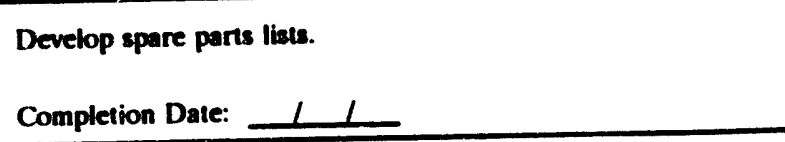 & & \\
\hline & & & Justification for NA: & & \\
\hline & & & & BWID Deptoyment & Dale \\
\hline
\end{tabular}




\section{BURIED WASTE INTEGRATED DEMONSTRATION PREPAREDNESS CHECKLIST AND ACTION PLAN (Demonstration and Research Projects)}

TTP No.:

PI Instructions: Input answer to questions using $\mathrm{Y}=$ yes, $\mathrm{N}=$ not addressed yet, and $\mathrm{NA}=$ not applicable. If response is $\mathrm{N}$, enter planned completion date in column 3 . If response is NA, complete justification section of column 3 . This should be periodically updated.

${ }^{*}$ Items must have either $\mathrm{Y}$ or $\mathrm{N}$.

\begin{tabular}{|c|c|c|c|c|}
\hline REQUIREMENTS & $\begin{array}{l}\text { COMPLETED? } \\
(\mathrm{Y}, \mathrm{N}, \text { OR NA) } \\
\end{array}$ & $\begin{array}{l}\text { ACTION REQUIRED AND EXPECTED COMPLETION } \\
\text { DATEJUSTIFICATION FOR NA }\end{array}$ & \multicolumn{2}{|c|}{ SIGNATURE BLOCK } \\
\hline \multicolumn{5}{|l|}{ 3.0 IHARDWARE PREPAREDNESS } \\
\hline \multirow[t]{3}{*}{$\begin{array}{l}3.10 \text { is equipment operational per } \\
\text { specifications? }\end{array}$} & & $\begin{array}{l}\text { Evaluate equipment specifications and capabilities. } \\
\text { Completion Date: }\end{array}$ & \multirow[b]{3}{*}{ BWID Deployment } & \\
\hline & & Justification for NA: & & \\
\hline & & 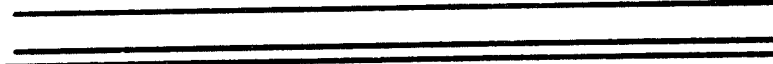 & & Date \\
\hline \multirow[t]{3}{*}{$\begin{array}{l}\text { 3.11 is equipment calibrated or standardized } \\
\text { per requirements? }\end{array}$} & & $\begin{array}{l}\text { Calibratestandardize equipment. } \\
\text { Completion Date: } 11\end{array}$ & & \\
\hline & & Justification for NA: & & \\
\hline & & & BWID Deployment & Date \\
\hline
\end{tabular}




\section{BURIED WASTE INTEGRATED DEMONSTRATION PREPAREDNESS CHECKLIST AND ACTION PLAN (Demonstration and Research Projects)}

TTP No.:

PI Instructions: Input answer to questions using $\mathrm{Y}=$ yes, $\mathrm{N}=$ not addressed yet, and $\mathrm{NA}=$ not applicable. If response is $\mathrm{N}$, enter planned

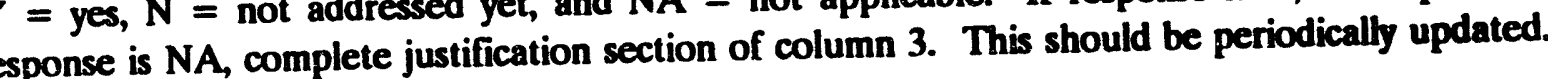
completion date in must have either $\mathrm{Y}$ or $\mathrm{N}$.

Instructions: To be completed when the entire checklist is completed.

I acknowledge that I have completed this checklist to the best of my ability as of this date.

NOTE: Approval to commence demonstrations will be granted.

WHEN: This checklist has been completed with entries either marked "Y" or "N/A"; it has been reviewed and approved by the BWID Deployment PM; and an approval letter has been transmitted from the BWID IDC to the PI. 


\section{Appendix B-2}

\section{Paper Study Projects}




\section{BURIED WASTE INTEGRATED DEMONSTRATION PREPAREDNESS CHECKLIST AND ACTION PLAN (Paper Study)}

Page 1 of 5

TTP Title:

TTP No.

PI Name:

Phone: $($ )

$\operatorname{Fac}(2)$

PI Instructions: Input answer to questions using $\mathrm{Y}=$ yes, $\mathrm{N}=$ not addressed yet, and $\mathrm{NA}=$ not applicable. If response is $\mathrm{N}$, enter planned completion date in column 3. If response is NA, complete justification section of column 3 . This should be periodically updated. *Items must have either $\mathrm{Y}$ or $\mathrm{N}$.

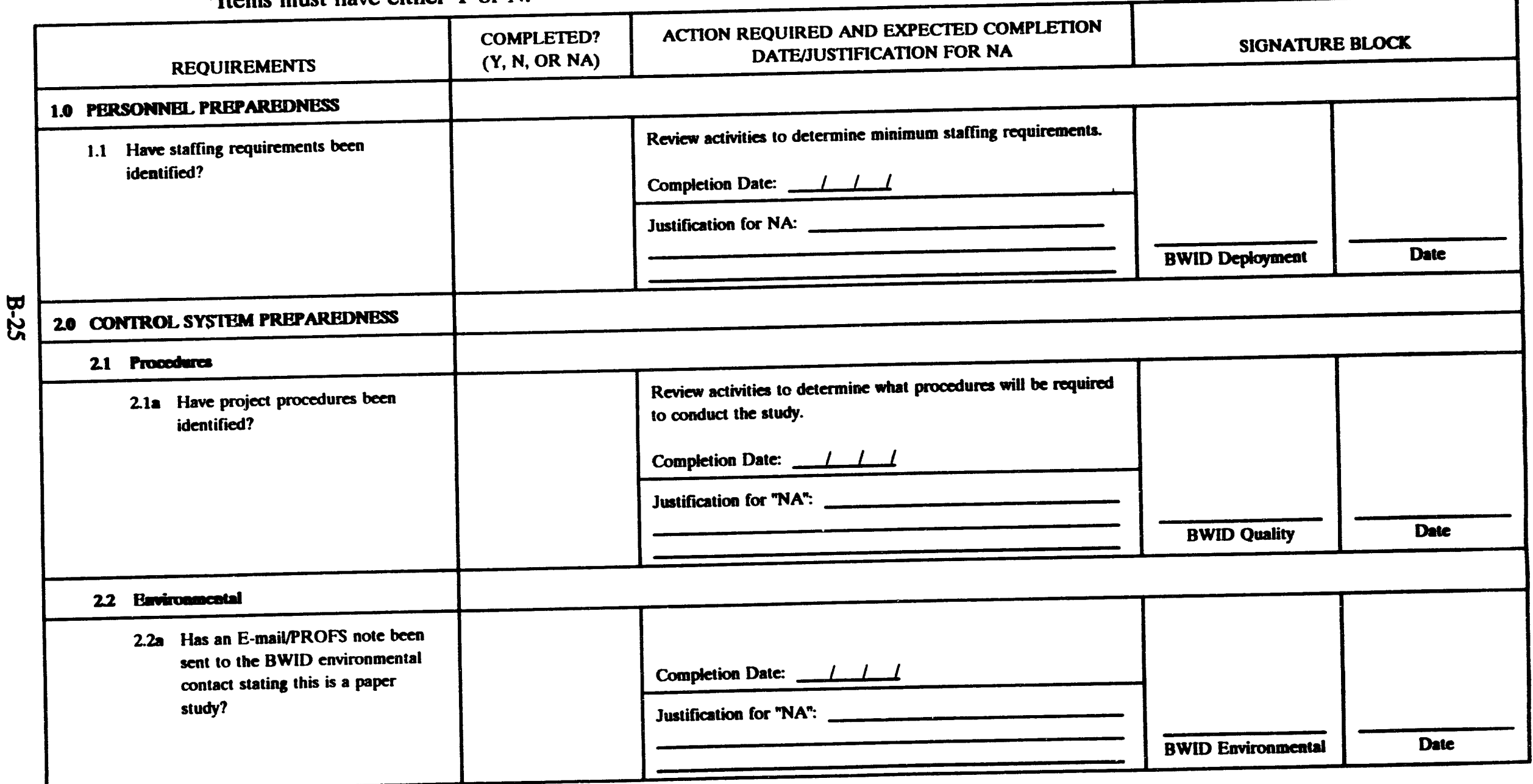




\section{BURIED WASTE INTEGRATED DEMONSTRATION PREPAREDNESS CHECKLIST AND ACTION PLAN (Paper Study)}

TTP No:

PI Instructions: Input answer to questions using $\mathrm{Y}=$ yes, $\mathrm{N}=$ not addressed yet, and $\mathrm{NA}=$ not applicable. If response is $\mathrm{N}$, enter planned completion date in column 3 . If response is NA, complete justification section of column 3 . This should be periodically updated. ${ }^{*}$ Items must have either $\mathrm{Y}$ or $\mathrm{N}$.

\begin{tabular}{|c|c|c|c|c|c|c|}
\hline \multicolumn{3}{|r|}{ REQUIREMENTS } & $\begin{array}{l}\text { COMPLETED? } \\
\text { (Y, N, OR NA) }\end{array}$ & $\begin{array}{l}\text { ACTION REQUIRED AND EXPECTED COMPLETION } \\
\text { DATEJUSTIFICATION FOR NA } \\
\end{array}$ & \multicolumn{2}{|c|}{ SIGNATURE BLOCK } \\
\hline \multicolumn{7}{|c|}{20 CONTROL SYSTEM PREPAREDNESS } \\
\hline \multicolumn{7}{|c|}{ 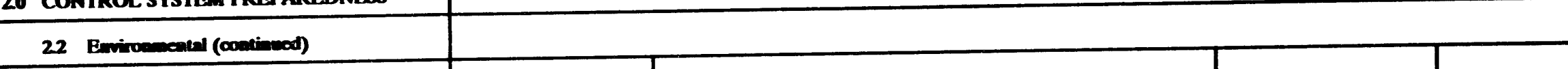 } \\
\hline \multirow[t]{2}{*}{ - } & \multirow{2}{*}{\multicolumn{2}{|c|}{$\begin{array}{l}\text { 2.2b Has EAP concurred that no NEPA } \\
\text { documentation is required? }\end{array}$}} & & & \multirow[b]{2}{*}{ BWID Environmental } & \\
\hline & & & & & & Dave \\
\hline \multicolumn{7}{|c|}{23 Ombing } \\
\hline \multirow[t]{4}{*}{ - } & \multirow[t]{4}{*}{2.3.} & \multirow{4}{*}{$\begin{array}{l}\text { Is a document control system in } \\
\text { place? (Should be addressed in the } \\
\text { Quality Plan or Project } \\
\text { Management Plan.) }\end{array}$} & & Developimplement control syatem. & & \\
\hline & & & & Completion Date: 11 & & \\
\hline & & & & Justification for "NA": & & \\
\hline & & & & & BWID Quality & Date \\
\hline \multirow[t]{3}{*}{ - } & \multirow[t]{3}{*}{$2.3 \mathbf{b}$} & \multirow{3}{*}{$\begin{array}{l}\text { Is a self-assessment system in } \\
\text { place? (Should be addressed in the } \\
\text { Project Management Plan or other } \\
\text { project document.) }\end{array}$} & & $\begin{array}{l}\text { Develophimplement a self-emesement system. } \\
\text { Completion Date: }\end{array}$ & & \\
\hline & & & & Juatification for "NA": & & \\
\hline & & & & & BWID Quality & Date \\
\hline
\end{tabular}




\section{BURIED WASTE INTEGRATED DEMONSTRATION \\ PREPAREDNESS CHECKLIST AND ACTION PLAN \\ (Paper Study)}

Page 3 of 5

TTP No.:

PI Instructions: Input answer to questions using $\mathrm{Y}=$ yes, $\mathrm{N}=$ not addressed yet, and $\mathrm{NA}=$ not applicable. If response is $\mathrm{N}$, enter planned completion date in column 3 . If response is $\mathrm{NA}$, complete justification section of column 3 . This should be periodically updated.

*Items must have either $\mathrm{Y}$ or $\mathrm{N}$.

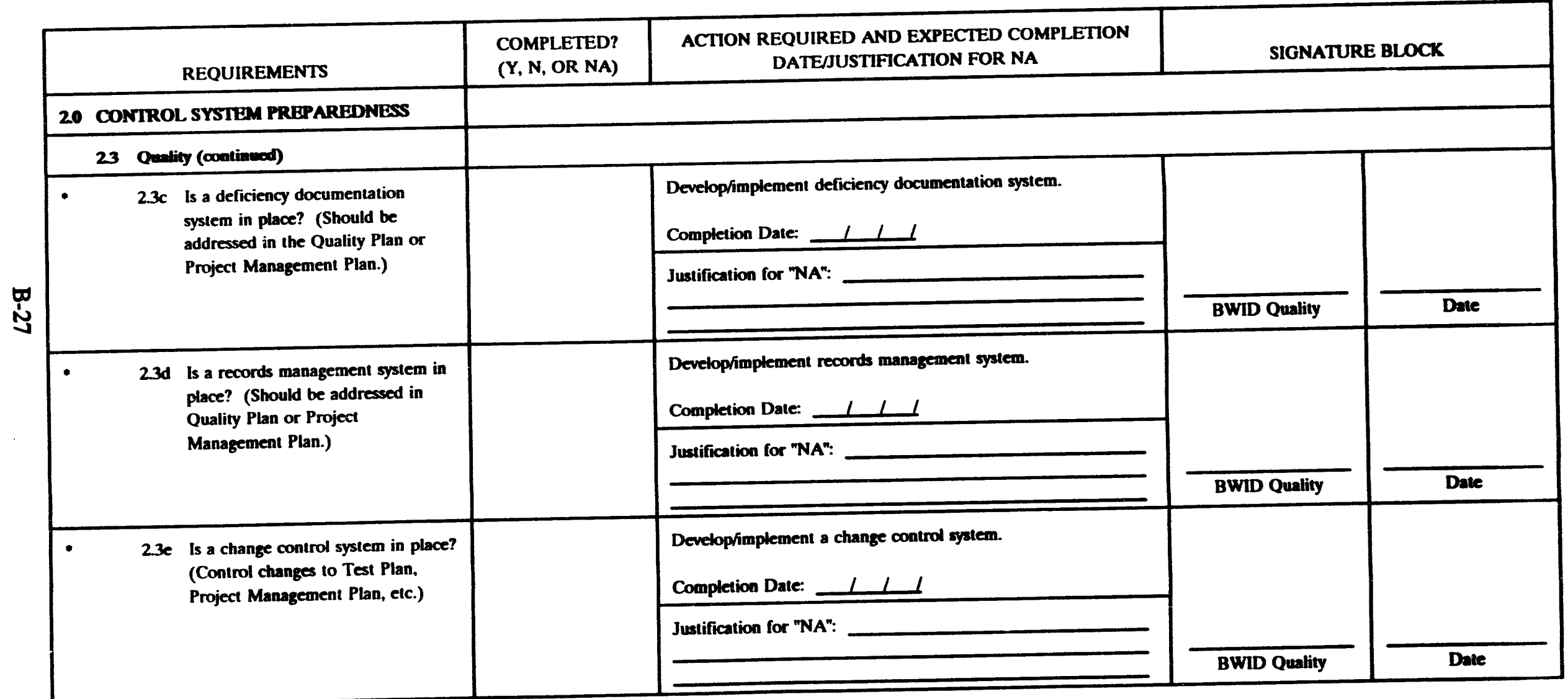




\section{BURIED WASTE INTEGRATED DEMONSTRATION \\ PREPAREDNESS CHECKLIST AND ACTION PLAN \\ (Paper Study)}

TTP No.:

PI Instructions: Input answer to questions using $\mathrm{Y}=$ yes, $\mathrm{N}=$ not addressed yet, and $\mathrm{NA}=$ not applicable. If response is $\mathrm{N}$, enter planned completion date in column 3 . If response is $\mathrm{NA}$, complete justification section of column 3 . This should be periodically updated. *Items must have either $\mathrm{Y}$ or $\mathrm{N}$.

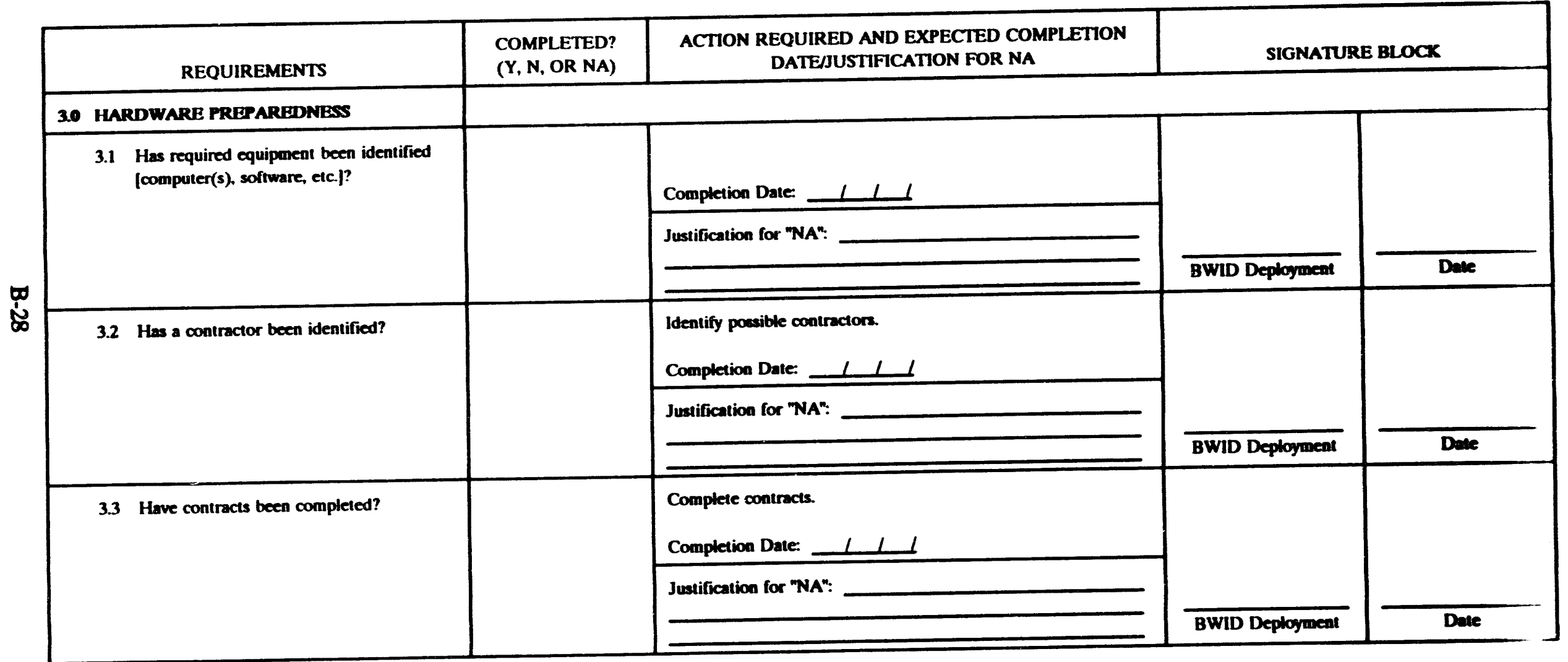




\section{BURIED WASTE INTEGRATED DEMONSTRATION \\ PREPAREDNESS CHECKLIST AND ACTION PLAN \\ (Paper Study)}

TTP No:

PI Instructions: Input answer to questions using $\mathrm{Y}=$ yes, $\mathrm{N}=$ not addressed yet, and $\mathrm{NA}=$ not applicable. If response is $\mathrm{N}$, enter planned completion date in column 3 . If response is NA, complete justification section of column 3 . This should be periodically updated.

*Items must have either $\mathrm{Y}$ or $\mathrm{N}$.

Instructions: To be completed when the entire checklist is completed.

I acknowledge that I have completed this checklist to the best of my ability as of this date.

PI

Date

Approval

BWID Deployment PM

Date

NOTE: Approval to commence demonstrations will be granted.

WHEN: This checklist has been completed with all entries either marked "Y" or "N/A"; it has been reviewed and approved by the BWID Deployment PM; and an approval letter has been transmitted from the BWID IDC to the PI. 
Appendix C

BWID Technology Commercialization Gulde

C-1 


\section{Appendix C}

\section{BWID Technology Commercialization Gulde}

The following model will be used to evaluate the commercial potential of BWID technologies. It focuses on 10 specific business and technical attributes. Based on the evaluation, technologies will be scored and ranked according to their commercial/implementation potential. Anowers to the queationnaire and commercialization action plams will be included in the Technology Preparedneas and Status Report (TPESR) for research projects (coe Appendix A-2). BWID staff will assist principal investigators in answering the questionnaire and preparing the action plan.

The commercialization model consists of both business and technical attributes, which are described below.

\section{Business Attrlbutes}

\section{Competitive Advantage}

"Competitive Advantage" describes what makes a product or technology better than what is currently offered in the marketplace. To gain a competitive advantage, the product or technology could cost less, perform better, have better durability, produce less waste, etc. The competitive advantage should be sustainable. That is, the competition should not be able to meet or better the technology easily.

2. Uniqueness (Evolutionary versus Revolutionary)

"Uniqueness" refers to whether the product or technology will "change the way people do business" (revolutionary) or whether the product or technology is a modification or slight improvement over currently available technologies (evolutionary).

\section{Potential Market}

Two aspects should be addressed when considering the market for a technology. First, potential partners that can commercialize the technology by manufacturing and distributing a product should be identified. Partners are critical because BWID is not in the business of manufacturing a product. Instead, BWID develops technologies. An industrial partner is needed to actually market, manufacture, and distribute a product. The second aspect of the market is end-users. This not only includes the DOE Complex Environmental Restoration and Waste Management markets, but also industrial segments such as the mining industry or agricultural industry. As much information as possible should be gathered to verify assumptions about market size, market growth, and external drivers. BWID's goal is to:

a. Find industrial partners to guide the development of technologies to meet market needs. 

b. Commercialize technologies once they have been demonstrated, teated, and evaluated.
c. Identify end-users.

The following schematic illustrates this concept:

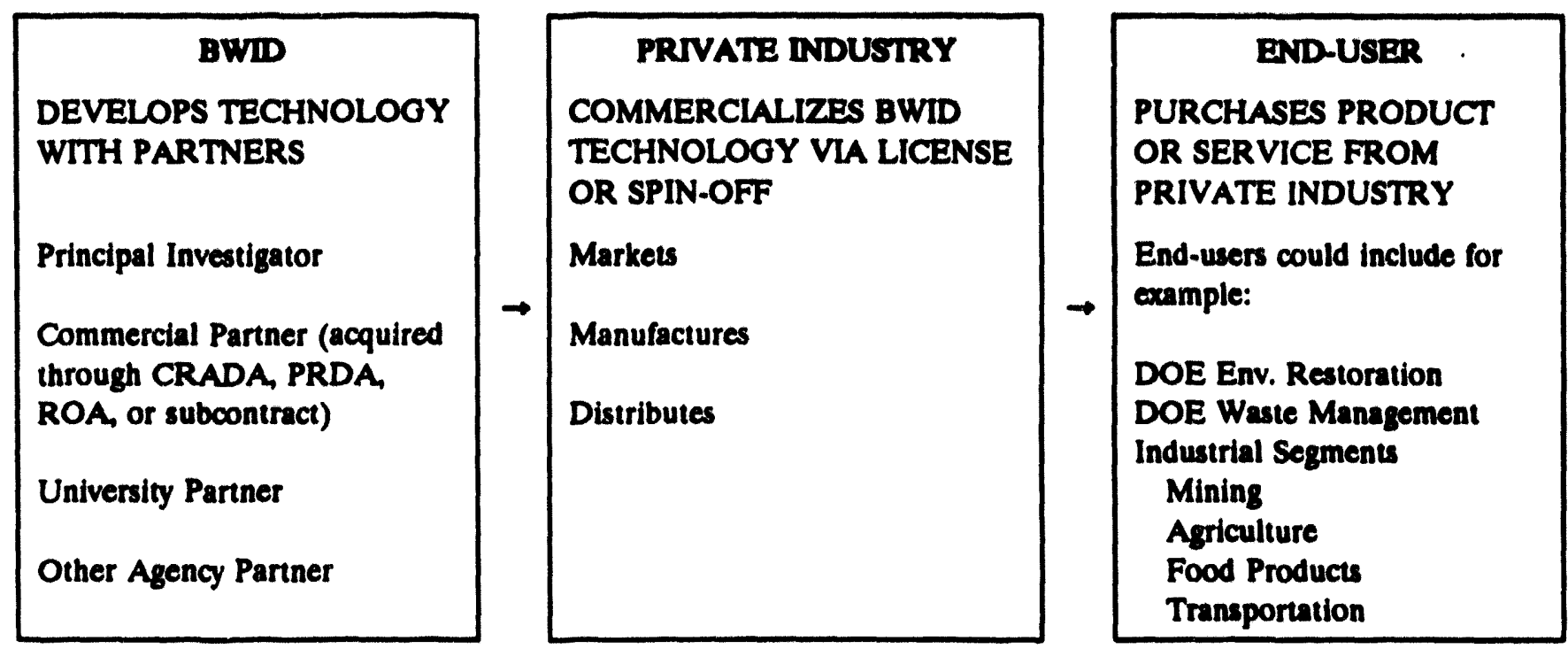

\section{Market Perception}

The market's perception of the product idea is assessed by subjective evaluation of how a potential user of the product or technology would react to the idea. This evaluation is based on the current approach to dealing with the problem and the ability of the market to recognize the superiority of the product. Can the market become aware of the product easily? Can they try the product with low levels of risk?

5. Market Compatibility

"Market Compatibility" is assessed by making judgment on the changes to the company's business operations that would take place if the idea were adopted (the technology is licensed). What changes to the licensing company's operations would have to be made: sales force, promotions, price structure, personnel, etc.? 


\section{Technical Attributes}

\section{Technical Compatibility}

"Technical Compatibility" examines how well the technology can be introduced into a company's existing manufacturing production systems. Can the technology be adapted readily with little need for additional support systems or major modifications to existing systems?

2. Complexity (Technical and Manufacturing)

"Complexity" is best illustrated by the following examples:

- A process has small moving parts that are susceptible to damage by dust and will be used in a dusty environment.

- The manufacturing process of a product will require special tools, dies, or machines that are either difficult to obtain or expensive.

- The manufacturing process will require tolerances that are not easily attainable.

3. Amount of Maturation

This category is a measure of effort required to bring the product to a level of technical maturity required for commercialization. What stage of development is the technology in? Has the technology been demonstrated?

4. Process Advantage

"Process Advantage" examines the extent to which the subject technology will make an existing process faster, safer, and/or less expensive? Will it produce a more robust product or result?

5. Scale-Up Risk

Most emerging technologies are confronted with the issue of taking development from the bench-scale stage to the full commercial stage. This is a critical, high-risk step in the evolution of most technologies. Consequently, it is important to assess the status of the technology with regard to scale-up. Has the technology been demonstrated at full scale? If not, what is the probability the technology will not work as intended at full scale?

\section{Directions}

Please answer the commercialization questionnaire first. After answering the questionnaire, prepare a commercialization action plan using the attached action plan as a guide. Include both answers to the questionnaire and the action plan in the TP\&SR. BWID staff will assist in answering the questionnaire and/or preparing the commercialization action plan. 


\section{Questionnaire}

Instruction: Answer the following questions to the best of your ability. For those questions for which you do not currently have answers, indicate how critical the answer is to the commercialization of your technology or product. Note: If you have previously completed the commercialization questionnaire, please update it to reflect current knowledge or information.

\section{Competitive Advantage}

1. Does your product or technology:

a. Solve a problem better than a competing technology(s)/product(s)? How?

b. Function better? How?

c. Produce outputs of better quality? Describe.

d. Have better durability? Describe.

e. Produce less waste? Explain.

f. Lower pollutants? How?

g. Have other qualities of unique competitive advantage such as size, safety, etc.?

h. Have easy to understand advantages?

i. Cost less to produce? Please compare to other technologies.

2. What competing technologies does your technology have to surpass?

3. What competitive advantages do the competing technologies claim?

\section{Uniqueness}

1. How much technological change would be required by a potential customer/partner to implement your technology?

2. Would the customer be willing to change to adopt your technology? How or why?

3. Is your technology revolutionary or evolutionary and why?

\section{Potential Market}

1. Describe your product or technology, what it does, and how it functions. Avoid scientific terms.

2. In what fields of use could this technology be applied?

3. List names of companies that may be potentially interested in commercializing your technology?

4. Who are the ultimate end-users of the technology? 


\section{Martet's Perception}

1. Will the market become aware of your product or technology easily? Why?

2. Will the market be able to try the technology with low levels of risk? Why?

3. Will the technology have any difficulties in being accepted by regulators? Discuss.

\section{Martet Compatibility}

1. If your technology or product was adopted, what changes to present operations would a company have to make? What type of development and engineering will they need to complete? What additional costs do they face? What impact will this technology have on their existing infrastructure of manufacturing, distribution, and sales?

2. If you should seek a private industry partner to commercialize your technology, how would your product fit into their business? What management and commercialization skills do they have, and are they financially strong? What motivates them to actively pursue business development of your technology? What would be the best partnering arrangement (CRADA, exclusive or nonexclusive license, etc.)?

\section{Technical Compatibility}

1. Will the technology or product require special support systems or major modifications to existing systems? (For example: Does the technology require special transport or skilled technicians with specialized training that are not currently used in the present process?)

\section{Complexity (Technical and Manufacturing)}

1. Does your technology require special conditions to operate? (For example: monitoring device is susceptible to high levels of humidity and, therefore, must have the environment controlled.)

2. Does the technology require special tools, dies, or machines that are difficult to obtain or are very expensive?

\section{Amount of Maturation}

1. What measurable performance has been demonstrated?

2. How much improvement and demonstration of the technology is likely, and when?

3. How long will it take you to reach commercialization of your technology? 


\section{Process Advantage}

1. What is the cost of competing technology in terms of both selling price and cost to manufacture?

2. How much, in your estimate, do you expect it would cost to produce your product or technology?

3. What is different about your technology that will make it faster, better, cheaper, or safer than competing technologies?

4. What is the intellectual property status on this technology? How do you propose to protect the intellectual property?

\section{Scale-Up Risk}

1. Has, or will, the technology be demonstrated at full scale?

2. If the technology has not been demonstrated at full scale, what are the risks associated with the technology not working at full scale?

\section{Commercialization Action Plan}

The following describes the elements that should be included in your commercialization action plan:

- Description of Technology

This section should include a short description of the technology. The description should be written so the informed general public could fully understand it.

- Market Overview

This section describes the market in general. Assess whether the market is growing, stabilizing, or declining. Also discuss how the entrance of your technology into the market would affect it.

\section{- Potential Customers}

This section should describe both potential end-users of the technology and potential partners who could commercialize the technology. Be as specific as possible.

- Competitors and Competitive Advantage

This section should describe what technologies compete with your technology either directly or as a substitute. Describe the competitive advantage of your technology and why it should surpass the competition. 
- Status of Intellectual Property

This section describes the status of intellectual property. Has an Invention Disclosure been submitted? Have any patents been filed? Provide all patent numbers and patent invention record numbers.

- Status of Technology Transfer

This section describes any technology transfer activities that have taken place so far.

- Action Items

This section enumerates that action items that must be taken to effect a technology transfer. Included should be projected completion dates for each item and the responsible party (BWID, ORTA, etc.).

- Commercialization Contacts

This section lists contacts, phone numbers, and addresses of firms interested in either partnering on the development of a technology or commercializing the technology. 
Appendix D

Industrial Hygiene Checklist

D-1 


\section{Industrial Hyglene Checklist}

The INEL/EG\&G Idaho industrial hygiene staff is required to address all occupational hazards originating from chemical, biological, physical, and ergonomic stresses. Specific requirements identified in the individual sections of the EG\&G Idaho Industrial Hygiene Manual are consistent with established policies set forth in DOE Order 5480.10 and DOE-ID 5480.1 Chapter X, both titled "Contractor Industrial Hygiene Program"; DOE-ID Order 5483.1A, "Occupational Safety and Health Standards"; and DOE-ID Order 5480.4, "Environmental Protection, Safety, and Health Protection Standards." For your specific TTP, you are requested to review the following list of hazards and requirements, and indicate whether or not any of them apply to your TTP demonstration and test at the INEL.

Your lab or contractor has in place an approved:

Hazard Communication Program

YES NO

Occupational Medical Program

YES NO

Carcinogen Control Program

YES NO

Chemical Hygiene Plan

YES NO

Will any of the following hazardous materials be used?

Beryllium (29 CFR 1910.1000)

Asbestos (29 CFR 1910.1001 and 29 CFR 1926.58)

YES NO

Formaldehyde [29 CFR 1910.1048 (b), (c-1), and (c-2)]

YES NO

Lead (29 CFR 1910.1025)

Benzene (29 CFR 1910.1200 and 29 CFR 1910.1028)

YES NO

YES NO

Acrylonitrile (29 CFR 1910.1045)

YES NO

YES NO

Demonstration/teat produces air contaminants:

(29 CFR 1910.1000 Tables Z-1-Z, Z-2, and Z-3)

YES NO

Special condition:

Temperature extremes (OSDC-ID12044-III E.2 ID 0550 5.4)

YES NO

Working in tanks and confined spaces (ANSI Z117, ID 0550 5.4, and 29 CFR 1910.141)

Special ventilation requirements (OSDC-ID 12044 III H1, ID 0550 4.2, and 29 CFR 1910.1000)

YES NO

YES NO

Special clothing, equipment, or facilities required (29 CFR 1910.141)

YES NO

YES NO

YES NO

YES NO

Nonionizing radiation (ANSI Z 136.1)

Equipment operating noise, 8-hr TWA of $85 \mathrm{~dB}(\mathrm{~A})$ or more

(29 CFR 1910.95 and ID 0550 5.4)

YES NO

List all other chemicals used in your TTP demonstration or test: 


\section{Appendix E}

Holsting and Rigging Checklist

$+$

E-1 


\section{Holsting and Rlgging Checklist}

This checklist is to be used if your project involves hoisting and rigging operations.

1. Equipment (crancafortlifts)

a. Nationally recognized manufacturer $\quad$ YES NO

b. Any modifications or additions that could affect capacity $\quad$ YES NO

c. Current inspection procedures for "frequent" and "periodic"
intervals

d. Current inspection procedures for "ordinary" "high-consequence," or "special high-consequence lifts"

YES NO

e. Current testing:

(1) Load test documented

(2) Tagged and dated

YES NO

(3) Rated capacity

YES NO

YES NO

2. Slings and rigging accessories

a. Current inspection procedures $\quad$ YES NO

b. Current testing:

(1) Load test documented

YES NO

(2) Tagged and dated

YES NO

(3) Rated capacity

YES NO

3. Personnel

$\begin{array}{ll}\text { a. Qualified operator } & \text { YES NO }\end{array}$

b. Qualified rigger $\quad$ YES NO

c. Qualified person-in-charge YES NO

d. Training record/resume documentation $\quad$ YES NO

Comments/justification for any of the above information: 

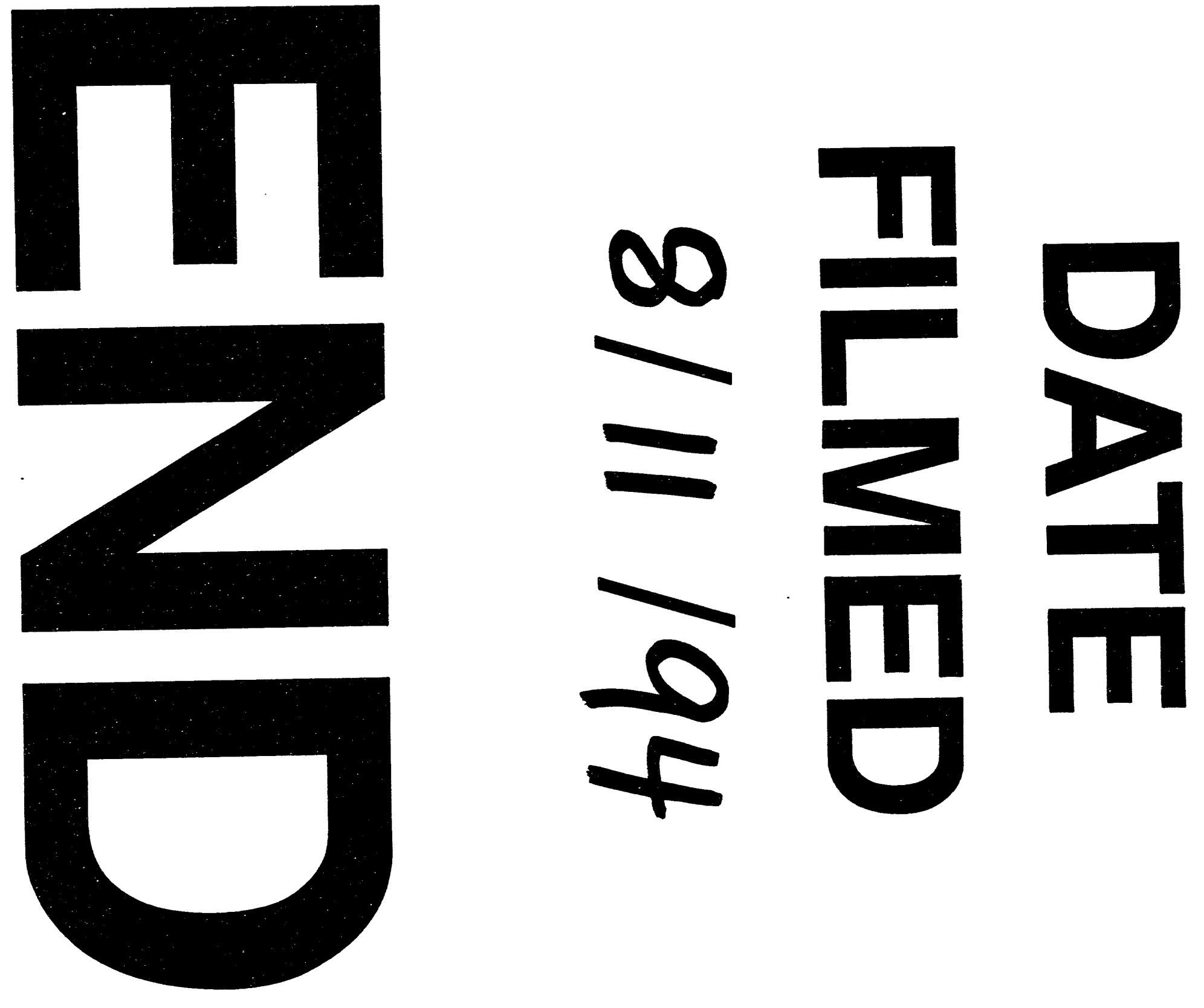


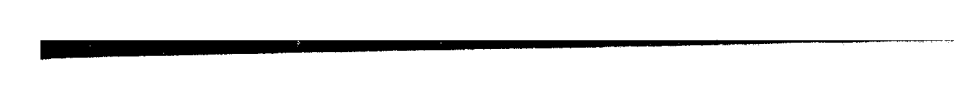

